The

Carl Beck

Papers

in Russian \&

East European Studies

Number 2005
Cynthia Simmons

\section{Women Engaged/Engaged Art in Postwar Bosnia: Reconciliation, Recovery, and Civil Society}

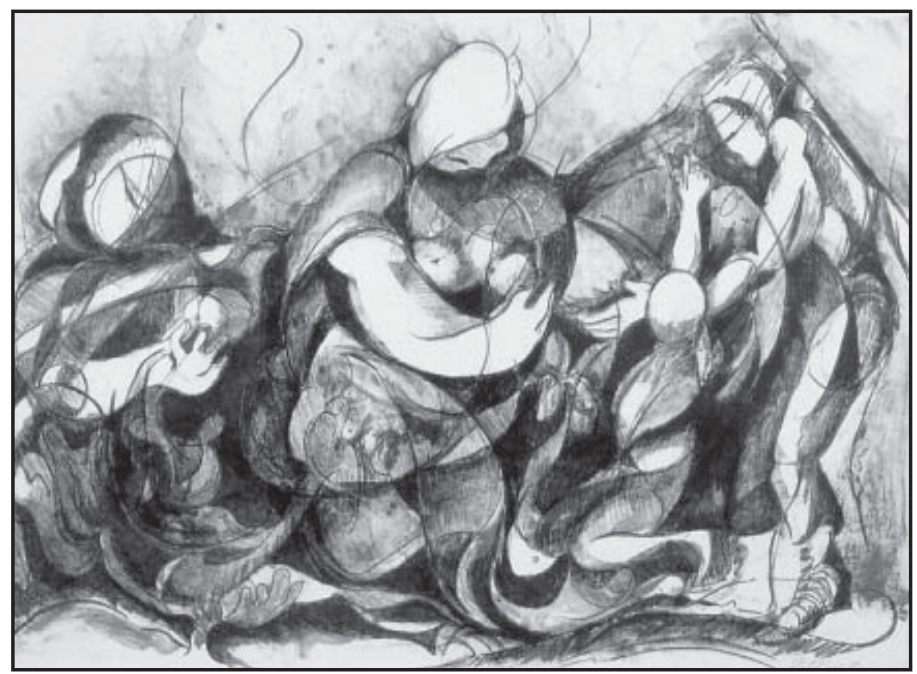


The

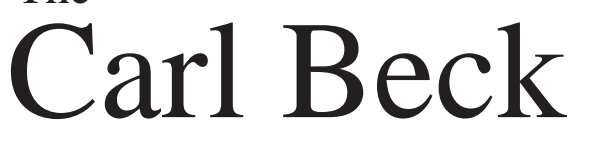

Papers

in Russian \&

East European Studies

Number 2005

\author{
Cynthia Simmons
}

Women Engaged/Engaged Art in Postwar Bosnia: Reconciliation, Recovery, and Civil Society 
Cynthia Simmons is Professor of Slavic Studies at Boston College. She specializes in cultural studies, literary theory, and the literatures of Russia and the former Yugoslavia. She has written on multiculturalism and women in nongovernmental organizations in Bosnia and Herzegovina and is the author of Writing the Siege of Leningrad: Women's Diaries, Memoirs, and Documentary Prose (with Nina Perlina), and Their Fathers'Voice: Vassily Aksyonov, Venedikt Erofeev, Eduard Limonov, and Sasha Sokolov.

No. 2005, June 2010 Second Printing.

(C) 2010 by The Center for Russian and East European Studies, a program of the University Center for International Studies, University of Pittsburgh

ISSN 0889-275X

Image from cover: Kate Page Korp, Sarajevo II. Printed with generous permission from the artist.

The Carl Beck Papers

Editors: William Chase, Bob Donnorummo, Ronald H. Linden

Managing Editor: Eileen O’Malley

Editorial Assistant: Julie N. Tvaruzek

Submissions to The Carl Beck Papers are welcome. Manuscripts must be in English, double-spaced throughout, and between 40 and 90 pages in length, including notes. Acceptance is based on anonymous review. Mail submissions to: Editor, The Carl Beck Papers, Center for Russian and East European Studies, 4400 Wesley W. Posvar Hall, 230 South Bouquet Street, University of Pittsburgh, Pittsburgh, PA 15260. 


\begin{abstract}
In postwar and post-Communist Bosnia-Herzegovina, civil society has been developing along with a significant recasting of women's roles in public life. Researchers have equated civil society since the war in Bosnia almost exclusively with non-governmental organizations (NGOs). Certainly this has been the most influential sphere of both women's work and of public activities contributing to a nascent civil society. Researchers have given insufficient attention, however, to the contributions of women in the burgeoning free press in Bosnia-Herzegovina, as well as to the increasing social engagement and influence of women artists and arts administrators. The contribution of the arts to civil society receives little attention, but women writers, artists, and arts administrators are addressing in their work and projects issues of justice, reconciliation, and human rights. Some who began their creative life in Yugoslavia, and who formerly sought independence from ideology in pure aestheticism, now embrace political engagement. They employ the potentially "free zone" of art to encourage the communication and mutual responsibility between the government and citizenry that underlies a civil society. Just as women have taken on new public roles since the waras directors in non-governmental organizations and as editors and journalists in the independent press - women artists are addressing specific postwar themes, and women arts administrators are promoting publications, creating exhibitions, and organizing events that draw attention to issues that are critical to the success of Bosnia's fledgling democracy.
\end{abstract}


This overview and analysis focuses primarily on women artists and arts administrators in the Federation of Bosnia and Herzegovina, and it is this entity that serves most often as a referent for "Bosnia." The situation and significance of women in the arts for the postwar situation obtain as well in the other entity of Bosnia-Herzegovina (BiH), the Serb Republic (Republika Srpska/RS). Yet, the cultural center of the country continues to be the urban capital of Sarajevo, in the Federation. Writers and artists from smaller cultural centers (Mostar, Tuzla, and, to a lesser extent the capital of the RS, Banja Luka), establish an artistic presence, in one way or another, in the capital. In addition, in the broader consideration of the influence of women in postwar $\mathrm{BiH}$, the Federation has witnessed the preponderance of new and changed roles for women. This situation reflects the realities of the Bosnian war - the particular plight of Bosniak (Bosnian Muslim) women as displaced persons, widows of war, and victims of rape, and in consequence, as recipients of humanitarian aid and other postwar efforts. Events in the 1990s and the first decade of the twenty-first century have effected considerable societal changes in the lives of women, and not only in the Federation. All women in BiH grapple with the aftermath, and to the extent that ethnonationalism continues to thrive, women confront cultural constraints on their agency. Nationalism generally (and certainly in former Yugoslavia) goes hand in hand with patriarchy. The rise of Islamic conservatism deserves special consideration, however, and it drives as well the focus of this study on women in the Federation. ${ }^{1}$

Although it is seldom the case, women should be at the center of any effort in the aftermath of war to achieve peace, reconciliation, and recovery. They often are left in the majority, following the deaths of male combatants. Although they may then represent the sector of society most in need, they have also become the greatest resource for restoring the nation's economy. Their participation is crucial; not only as members of the labor force, but also as providers for their families. Many women have become single heads of household, and they require, in addition to humanitarian aid, the education and training necessary for employment. Finally and perhaps most important for the full recovery of a nation scarred by war, women nurture and protect children, the generation that holds the best hope for reconciliation. ${ }^{2}$

The fate of women during and since the war in Bosnia and Herzegovina holds true to this typical scenario. Large numbers of women civilians suffered direct personal attacks or the loss of their (predominantly male) relatives and homes. According to an estimate characterized as "low," twenty thousand women (mostly Muslim) were raped. ${ }^{3}$ Of the approximately one million people who were internally displaced during the war (with another million having emigrated), the State Ministry 
for Human Rights and Refugees of Bosnia and Herzegovina estimated in June 2008 that about one hundred twenty-five thousand registered internally displaced people remain. No statistics exist on the number of women who were widowed during the conflict, and there is no reliable way to determine the breakdown by gender and over time among those internally displaced. Yet, certainly in the areas in eastern Bosnia that were ethnically cleansed, the majority of those displaced were women and children. And whether women were accompanied by a male head of household or not, studies have shown that women suffer in particular as displaced persons. ${ }^{4}$

The Bosnian conflict has had a predictably devastating effect on the lives of women in Bosnia and Herzegovina. Yet, as gender and war studies have proved, the chaos of war often provides women with opportunities to expand the boundaries of their traditional roles. The most dramatic changes in the status of women in the Western world came as a result of the Bolshevik revolution and two world wars. ${ }^{5}$ Women's roles - in support positions and even in direct combat - precipitated the political and societal changes that organizers in the women's movement were demanding even before these cataclysmic events. More recently, the social upheaval of war has affected women in other parts of the world similarly. Following the 1994 genocide in Rwanda, the new government adopted legislation that gave women inheritance and property rights for the first time. In Afghanistan, women who were cloistered away from society under the Taliban regime (having lost the rights they enjoyed when the country was under Soviet domination) now are guaranteed seats in Parliament. ${ }^{6}$

Women in modern Yugoslavia enjoyed the freedoms guaranteed them by their communist ideology, and they were articulated in the country's 1946 constitution. ${ }^{7}$ In many areas of public and economic life in modern Yugoslavia, women made considerable gains. The percentage of women enrolled at universities rose from nineteen percent in 1939, to 40.3 percent in 1973-74. The percentage of women in the work force rose from 18 percent in 1940, to 34.7 percent in $1978 .{ }^{8}$ Nonetheless, Bosnian women today, who carry much greater responsibility for the survival of their country than they did before the war, also have experienced opportunities in the public sphere that were unavailable in communist Yugoslavia. Of the various arenas in which women contribute to public life and welfare today in Bosnia, including nongovernmental organizations, journalism, business, and government, we focus here on a sector that often goes unappreciated in studies conducted primarily from a social-science perspective - the arts.

Whether we consider the arts through the Bakhtinian prism of "carnival" and liminality or the Turnerian understanding of the important work of the "play" of the 
arts, we find theoretical support for what appears intuitively obvious, that "artists provide us with new and innovative ways of seeing the world." The borderline space in which art is produced — and the future is imagined — can serve (like independent media) the free zone of civil society, where it is possible to discuss and critique the present. In the fragile peace of a traumatized society, there is little official encouragement for an open exchange of ideas or the expression of frustrations. Yet, both of these activities are necessary for reconciliation and for the fostering of a culture of the open exchange of information and opinions that is crucial to democratization. Numerous writers and artists in Bosnia have dedicated their talents to an art that engages with the crucial issues facing postwar Bosnia. Many of them have turned from a prewar aestheticism to a new (for them) civic art.

The privileged borderline perspective that some critics consider to be the hallmark of art at its best, and the creative independence of all practitioners that we associate with art in the West, were not artistic norms in modern Yugoslavia at the time of its formation in 1945. Tito's break with Stalin and the Soviet bloc in 1948 spared Yugoslavia from the implementation of the tenets of socialist realism. Yet, even after the break, expectations that the arts were to "serve" the new nation prevailed. The critical difference for Yugoslavia is that dissent was, for the most part, tolerated. A critical number of influential writers railed against the ideological restraints on the arts under communism. ${ }^{10}$ This opposition distinguished the world of art in Yugoslavia, and except for open criticism of Tito, the government, or the party, art in Yugoslavia remained relatively "free." Most writers and artists associated tendentious or "engaged" art with the Soviet oppression that Tito rejected. The willingness of some since the war in $\mathrm{BiH}$ to "engage" and dedicate their work to the consideration or amelioration of social ills marks a significant change of course.

A turn in postwar Bosnia and Herzegovina to civic art characterizes the work of some male writers, artists, filmmakers, and arts administrators as well. Yet, there is ample reason to focus on the role of women in this change of direction. We noted above the vulnerability of women in war as well as their particular plight and responsibilities when peace returns. The ways in which women respond to war and the aftermath often put them into direct conflict with policies and (male) actors that they hold responsible for the fate of their community. As the director of the Soros Center for Contemporary Art (now the Sarajevo Center for Contemporary Art) Dunja Blažević observed in her profile of three women artists whose work was transformed by the war (Alma Šuljević, Anela Šabić, and Suzana Cerić): "Even if their work is not explicitly feminine, it clearly [implies] a criticism of the ruling male principle and the patriarchal morality." "11 Engaging in "engaged" art can effect to some degree 
the empowerment of women (for the artist as well as the woman experiencing the art). That empowerment has been fostered even further in some cases by the financial support that women in the arts have received. International agencies have often favored women in postwar BiH-women's organizations, women directors, and individual women, including women artists, who share their goals. Some women writers, artists, and arts administrators have commanded attention (as in some other successor states to Yugoslavia) by virtue of their "message" and, in some cases, have benefited from expanded access and sponsorship for their work. ${ }^{12}$

What is specific to Bosnia, and more difficult to research, is the conflict that must arise when such women path-breakers in the arts attract the attention of cultural and religious conservatives. During and since the war, women have born severe, and in some instances, unique trauma. In the aftermath, some women now exert, in certain arenas, unprecedented influence on Bosnian society. Among these, women in the arts are engaging in "engaged" art. Yet, we cannot overlook certain equally unprecedented obstacles to women's postwar agency - a subject we will return to below.

\section{Literature}

\section{Prose}

During and soon after the end of the Bosnian War (1992-95), and with the crucial support of the Soros Foundation's Open Society Fund, writers "wrote" the war. The crucible of war informed the work of writers of all generations. A glance at the corpus of publications, 1992-96, reveals the names of writers who were already well established (such as Ferida Duraković, Miljenko Jergović, Semezdin Mehmedinović, Josip Osti, Abdulah Sidran, and Marko Vešović) and of others whose varying talents were forged or released in that wrenching reality (such as Muharem Bazdulj, Šejla Šehabović, and Fahrudin Žilkić). ${ }^{13}$

More recently other considerations have come to the fore. Many writers and artists have chosen to focus in their art on the restructuring and reconstruction of postwar and postsocialist Bosnia. As outlined above, the success of these efforts depends in large part on the amelioration of hardships endured by women as a result of the war. Women in the arts are addressing in various ways the most pressing issues of life in Bosnia and Herzegovina. Many women writers are engaging, explicitly or implicitly, in the public debate over justice and reconciliation, multiculturalism, and Bosnian identity. Some among them deal more narrowly with these general societal 
concerns and by considering them with respect to life lived as a Bosnian woman before and since the war. We will distinguish between women writing, engaging the broad societal questions of the day, and "women's writing" (ženkso pismo), which may consider the very same issues, but from a particular female perspective.

With respect to women's writing, a seminar in the Department of Comparative Literature at the University of Sarajevo concluded that in Bosnia and Herzegovina the basic questions of feminist literary criticism have still not received, even at the beginning of the twenty-first century, the attention they have been accorded in most other European literatures:

U zamršenim i antagonističkim odnosima "književnosti naroda" Bosne i Hercegovine, problem "ženskog pisma" i ženskog subjekta ili je marginalan, ili jednostavno ne postoji. ${ }^{14}$

(In the complicated and antagonistic relations of the "literatures of the nations" of Bosnia and Herzegovina, the problem of "women's writing" or the woman subject is either marginal, or simply does not exist.)

What the literature itself suggests is that the war and its aftermath still dominate thematically in much of contemporary Bosnian literature. However, in important works by women writers, the war or general postwar situation in the country provide the context for more central concerns - life lived as a woman or as a woman writer in postwar Bosnia.

The Sarajevan writer Alma Lazarevska wrote one of the more artistically significant and emblematic works of literature to come out of the war. It is also noteworthy that the recognizably female consciousness in the collection of stories Death in the Museum of Modern Art (Smrt u Muzeju moderne umjetnosti, 1996) presents as her most salient identifying characteristics her roles as a writer and an intellectual under siege. As we might expect, the stories in Lazarevska's latest collection, Plants Are Something Else (Biljke su nešto drugo, 2003), allude less to the particulars of the war. ${ }^{15}$ But as we find in literature written ten years after the war, or more, the events of 1992-95 still inform most writing. At the same time, we can often identify a shift in emphasis in these stories. The female narrator or author persona (not all stories are told from a female voice) reflects, as in Lazarevska's earlier prose, a biography similar to her own. The woman, a mother, is a university-trained writer, well versed in Western European literature. Although the profile remains the same, we sense that the experience of war and the mindset of the intellectual receive less scrutiny in these later stories than life lived as a woman. If we recall the relationship historically between war and women's empowerment, the shift in focus in the writing of 
this one woman writer hardly seems unexpected. Just a few examples from Plants Are Something Else serve to reveal a shift in the hierarchy of salient features of the protagonist. Artist and intellectual are supplanted by "woman."

The eponymous story of this collection, "Plants Are Something Else," provides the emblem of this shift in saliency. A short, though dense, narrative at the end of the collection, it leaves a lingering impression. Emanating from the husband's voice, the story conveys little information about the narrative present. Rather, it implies. The reader senses that experiences during the war still carry both overt and subliminal significance. It is likewise left to the reader to ferret out the source of tensions or the meanings of cryptic communicative acts.

We do not know the reason for the tension between husband and wife. She is distant and judgmental; he is confused, defensive, though still desiring. He attempts to connect with her interest in her plants and comments that her creeper is "slow," knowing, as he says it, that it is incorrect, not the way one talks about plants. He imagines her response: "Animals are slow or fast. Plants are something else" (146). He imagines as well that as she waters her plants, she repeats, like a mantra, its Latin name, and that she does this so as not to recall the body counts that are imprinted on her memory. (Is this just projection? As he ponders the reason for her behavior, he experiences his own flashbacks.) The husband feels further indicted by his wife for their son's "experiment" with a piece of paper. He has learned that by holding it just the right way, the sharp edge can serve as a knife. With his newly fashioned implement, or weapon, he cuts a leaf of new growth from "mother's" plant. Although the reader has no access to the woman/wife/mother's thoughts, and she speaks only a few lines, she, and what her husband — and we - imagine her thoughts to be, dominate the story. The atmosphere is charged with haunting memories and unresolved concerns. It is crucial that her husband wants to understand his wife, values his intimacy with her, and fears, we sense, losing her. Strangely, the story offers hope for the postwar and postsocialist Bosnian woman.

We cannot leave this collection or the story "Plants Are Something Else" without noting that in the seeming coda to this story, our attention is returned, by implication, to the war, and the way that experience has "double-voiced" all interactions. The narrator wonders why he had followed his wife into the bedroom. He then recalls a similar scene from the past, "older than the siege and the time when the foreigners arrived," when he watched his father follow after his mother, who had left the room. When he found her in another room, he said: "Oh, you're here. And I was afraid that you ... were gone" ("A se uplašio da te ... nema") (147-48). This need to affirm the presence of a loved one and the recurrent joy of reunion are only magnified by the experience of war. ${ }^{16}$ The postwar fear (conscious and unconscious), 
which is allayed with each "return" of the loved one, figures in the ongoing process of recovery. Lazarevska's collection addresses not only the concerns of the Bosnian woman, but of all the survivors, who, often in spite of appearances, continue to deal with consequences of the war.

Another woman writer, Jasna Šamić, addresses in both her life and work less typical experiences, for women and others, during and since the war. She is foremost a scholar of Islam, a Muslim woman "Orientalist" who lives nonetheless a "secular" Muslim life. Her novel Room with an Ocean View (Soba s pogledom na okean, 2001), in which she writes candidly from the perspective of a (highly autobiographical) female refugee/ex-pat in France, has received considerable attention for its artistic merit. ${ }^{17}$ Yet, she has had to face criticism from both the liberals, for having published in the conservative journal Ljiljan, and from conservative Muslims for the frankness of her writing and for her personal life choices.

Shortly before the release of Room with an Ocean View, Šamić gave a lengthy interview to the chief editor of the independent news weekly Dani (Days), Senad Pečanin. Her answers to Pečanin's often provocative questions proved equally provocative. When asked why she had received the epithet in certain Parisian circles of "fundamentalist," she replied that she could in part thank the editor of Dani himself:

You are the guilty one. . . The reason was that I wrote for Ljiljan. . . . When I met you in Zagreb in 1994, on my way to Sarajevo, you told me that you had wanted to hire me to write for Dani, but that you no longer wanted to because I was writing for Ljiljan. That was when it really dawned on me and it took me back. I have to tell you (although reluctantly, because it seems like a justification, and I don't feel guilty) that Ljiljan was the newspaper that, with its name, evoked in my mind medieval Bosnia, the culture, diversity, and independence of all of Bosnia, and not merely the paper of Muslims or "fundamentalist-oriented Muslims." 18 What is more, I had in mind the situation before the war when everyone could publish anywhere, and that that wouldn't invoke shame or suspicion; finally, when I began to write, I hadn't seen that newspaper. Later I saw in it articles by many well-known journalists and writers from ex-Yugoslavia. Recently the writer Dževad Karahasan confirmed for your paper that he has written and will in the future write for Ljiljan. In France he received an award as a democratic writer, in Strasbourg he is on a commission for the protection of human rights - thus an author who still today writes for Ljiljan, and shields himself from me because I wrote for that newspaper for a year. These paradoxes I don't understand. And first of all it's necessary to read what I wrote, and then critique; my articles are published in my book as well. Let's not forget that Igor Mandić and Predrag Matvejević and Miljenko Jergović have written for this paper, not to mention the "fundamentalists" Glucksmann and Finkelkraut, etc. None of them, however, is a fundamentalist; I am the 
only one, even though I was writing at the same time for other newspapers:

Liberation, El Mundo, etc. ${ }^{19}$

Later in the interview Pečanin asks Šamić to respond to a withering review in Dani of her earlier novel Frost and Ashes (Mraz i pepeo, 1997) by Asmir Kujović. Kujović (a Bosniak) describes the female author of one of the diaries that comprise the novel (and the seeming author persona) as "sexually threatened" and accuses Šamić, whom he refers to condescendingly as "Šamićka," of descending to the level of Erica Jong. ${ }^{20}$ These diametrically opposed perspectives on Jasna Šamić—sexually explicit/obsessed and "fundamentalist" - appeared within a year of each other in (the liberal) Dani. As a Muslim woman intellectual and writer, she has come into direct conflict with religious conservatives and secularists, and it seems, a patriarchy that characterizes both.

Room with an Ocean View begins as a first-person narrative of Mira, a Bosnian musician. ${ }^{21}$ The novel chronicles nonlinearly in three parts the experiences, and more significantly, perhaps, the musings of a woman who finds herself abroad in France at the start of the Bosnian War. The second part (narrated from the third person) provides Mira's "back story" - the unrequited love that defined her adult life and the circumstances that led to her decision to return to her son in France at the start of the siege of Sarajevo. In part three Mira describes her homecoming after the war. She relives the deaths (and particularly of her beloved aunt) that she had previously experienced from afar. And she confronts mutual misunderstanding in the "new" Bosnia. Although not strictly autobiographical, some of Mira's experiences mirror closely those of Šamić - most notably, in connection with the interview above, Mira too writes for a publication back home which, it turns out, is Bosniak and not "Bosnian." She too suffers "bad press" in France, where she is accused of opposing mixed marriages, even though she has one.

Mira bears the stigma of one who did not experience the war firsthand and "can never know." When she returns to Sarajevo, she is no longer considered "one of us" (naši) and is denied a teaching position at the (Musical) Academy (despite the desperate need for faculty) or the opportunity to perform. Her apartment has been given to the family of a šehid (martyr), the term used routinely for any Muslim man who died as a result of the Bosnian war.

For her part, Mira has little sympathy for what she considers to be an ahistorical, intolerant, and anti-intellectual pursuit after the war of a strictly Bosniak (Muslim) national identity. She is surprised and irritated when, at a café in the historic old market of Sarajevo (Baščaršija) where she has met a friend, the waiter responds to 
her order of a glass of wine: "We don't serve wine, this is a national restaurant" (209). Mira asks the waiter whether he has heard of akšamlučenje, a word obviously of Turkish, and therefore Muslim, origin (akşam Turkish for "evening"). Mira is referring to a Bosnian social gathering - in the waiter's memory of prewar Sarajevo, as in Mira's, accompanied by the drinking of alcoholic beverages. She adds for good measure: "Surely that expression didn't originate in the Latin Quarter" ("Taj izraz sigurno nije nastao u Latniskoj četvrti"). Mira is even more disconcerted to realize that a conference on Bosnian music in Sarajevo, which she has been invited to attend, has little to do with music but serves to glorify the Bosniaks as "the oldest, the most noble, the most tolerant, the most spiritual, the most progressive, the most educated, the most talented, the most musical, the most charming, the most beautiful . . p people" (226). She "learns" there that Bosniaks, in fact, are not Slavs; that there are no Slavs in Bosnia. The original Bosnians predate the Slavs and are an autochthonous people, who can be distinguished from the Slavs across the rivers from Bosnia and Herzegovina by certain facial characteristics (227). In Šamić's novel, there is a dovetailing of the personal and female with the public and universal. Part three, in particular, contributes to the dialogue initiated by other women writers as well, which addresses a seemingly intractable nationalism and growing religious conservatism.

In her more recent Kingdom of Shadows (Carstvo sjenki, 2007), Šamić takes a similar narrative stance. ${ }^{22}$ A seemingly autobiographical narrator (like Šamić herself, a specialist in literature, trained in France, and a filmmaker) is traveling by train from Strasbourg to Paris. She begins reading the correspondence that has come into her possession since her mother's death, between her mother in Sarajevo and her father, working in France, in the late 1950s and early 1960s. In this work, designated on the title page as a novel, the narrator/author persona memorializes her mother. Yet, as the title indicates, the narrator's recollections call forth other "shadows." The real and figurative deaths of A Room with an Ocean View "surface" in this work as "shadows" of people and events spanning the narrator's childhood in Yugoslavia, the war, and the aftermath. The narrator recounts events from her childhood, and Šamić, through her, reconsiders the experiences of Bosnians (and Bosniaks) in Tito's Yugoslavia.

The reconsideration of the past that characterized early post-war literature continues. ${ }^{23}$ The discerning of the "truth" that is necessary for reconciliation has been taking place among artists as well as historians. The narrator's recollections of her family's interethnic relationships are triggered by her memories of her mother 
and they include a reconsideration of ethnic distinctions that had less saliency for her and others in the era of her childhood:

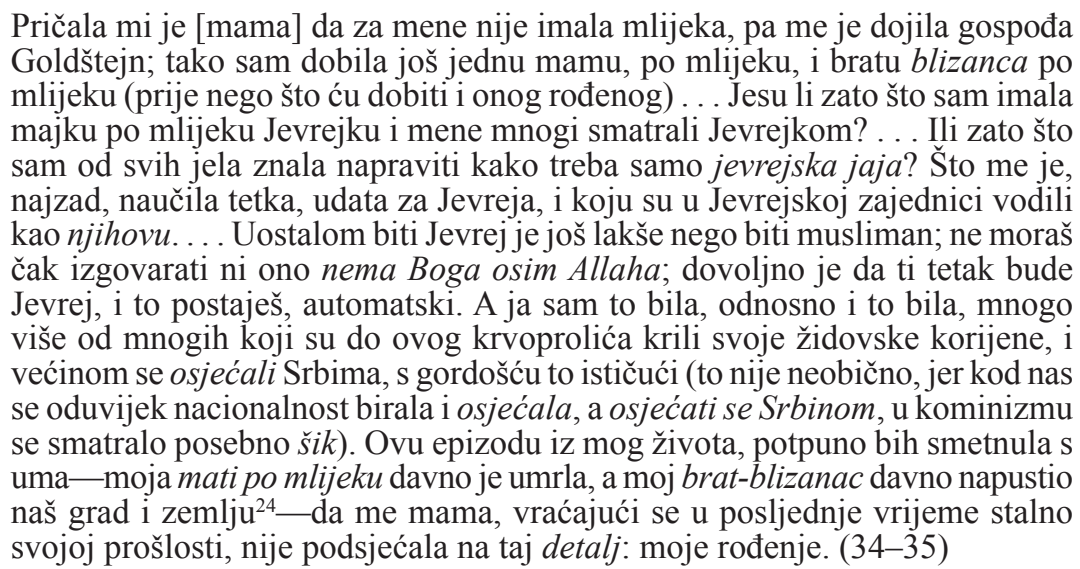

([Mama] told me that she didn't have milk for me, so I was nursed by Mrs. Goldstein; thus I got one more mother, a "milk" mother, and a twin "milk" brother (before I got the real one).... Was it because I had a Jewish "milk" mother that many people considered me a Jew? - Or because the only dish that I knew how to make properly was Jewish eggs? Or finally, because I was taught by my aunt, who married a Jew, and who was treated in the Jewish community as one of their own. . . . After all, it's easier to be a Jew than a Muslim; you don't even have to recite that there is no God except Allah; it's enough that your uncle is a Jew, and you become one, automatically. And I was one, relatively speaking, more than many who before this bloodbath hid their Jewish roots, and the majority of whom felt they were Serbs, stressing this with pride (this wasn't unusual, since nationality is something that we have always chosen and felt and to feel oneself a Serb, under communism, was considered especially chic). I would have wiped this episode of my life completely from my mind-my milk-mother died a long time ago, and my twin brother long ago left this city and land - if my mother, recently returning constantly to her past, had not reminded me of this detail: my birth.)

In other recollections, the narrator recalls that her mother often decried the material losses her family (of aristocratic Bosniak heritage) suffered with the confiscation of property under communism. She railed against the "system," and expressed pride in the tolerance (of Jews and Catholics) that she claimed as characteristic of her family's attitudes and behavior (41). Recalling her mother, the narrator remembers and reveals complex realities that received relatively little attention in Tito's Yugoslavia, and particularly when they ran counter to the prevailing ideol- 
ogy of communist "brotherhood and unity." The family's "tolerance" of Jews and Catholics implied condescension, and in private, her mother expressed openly her antipathy toward communism. In her reconsideration of the reality of Bosnia and Herzegovina in modern Yugoslavia, Šamić contributes to the pursuit of "truth," as a first step toward reconciliation.

Lazarevska and Šamić call attention in varying ways to specific concerns in Bosnian culture (for women and for society at large), as does Nura Bazdulj-Hubijar, the most prolific and best-selling woman writer in $\mathrm{BiH} .{ }^{25}$ Bazdulj-Hubijar has written for various audiences, including acclaimed works for children and adolescents. She admits readily in interviews that she has written on the war as therapy for herself, to give young people hope, and to warn against the moral and emotional bankruptcy of vengeance: "The goal of my writing is that people, after reading my text, will be at least a little bit better. So I am glad when people recognize the impulse. . . . As someone who lost twenty relatives in this war and whose mother was killed by a shell, I don't want hatred to ever enter my heart. In that sense Mirza [the young boy writing letters to his dead father in Once in July] is, in fact Nura." ${ }^{" 26}$ A physician by training, Nura Bazdulj-Hubijar writes well within the tradition of doctor/writer/ healer, as well as fulfilling the traditional role of a woman as arbiter of morality. ${ }^{27}$ In 2005, she received an award from the Croatian publishing house V.B.Z. and the newspaper Večernji list (Evening Paper) for the best unpublished novel of the year, Once in July (Kad je bio juli), an epistolary novel written as a letter from a son to his father, who died in the massacre at Srebrenica in July 1995.28

In Once in July Bazdulj-Hubijar mimics in writing the dialect spoken by her narrator Mirza, left alone when his mother and sister fled the Serb attack on their village. His mother had told him to hide - she knew that a male child's chances for survival would be better if he did not leave the village with the rest of the refugees. Mirza makes his way on his own, and when he is moved by the ten-year anniversary of the Srebrenica massacre to remember and to express his thoughts in letters to his missing father, the reader learns of the people and events that marked his journey.

Mirza reveals that as a child he had dreamed of becoming a writer. His colloquialisms, misspellings, and nonstandard grammar attest poignantly to an education curtailed by the war, and to the loss of that dream. Still, the would-be poet shines through, as Mirza contemplates the nature of evil and evildoers, questions his faith and the existence of God, and marvels at the depth of human suffering and the resilience of the human soul. He describes alternately his contemporary life situation in 2005 and his flight from his native village to the "safe area" of Srebrenica. He feels fortunate to have found work and that his boss treats him as an equal, praises his 
innate intelligence and encourages him to pursue the education he missed as a child. Mirza juxtaposes these "saving graces" to the horror he saw and many experienced during that July of 1995, writing that it was surely hell (džehenem) on earth. ${ }^{29} \mathrm{He}$ could imagine nothing worse.

Mirza's last letters to his father serve well Bazdulj-Hubijar's stated conviction to choose hope over despair. He reveals that he has fallen in love and has become engaged to Biljana, an ethnic Serb. Biljana's parents give their blessing, and Mirza's boss rejoices at the news and that "there'll be someone to preserve 'brotherhood and unity" (153). Only Mirza's aunt, who with her daughter are Mirza's only known surviving relatives, objects to the marriage. She accuses Mirza of having gone madhow else could he think of marrying a "Chetnik" (četnikuša)? Mirza threatens never to cross his aunt's threshold if ever again she speaks against Biljana. Although Mirza laments the proliferation since the war of mosques and churches when so many other new buildings are needed, and because they express the differences among religions rather than the "one God" that his father and his boss and mentor profess, he is comforted by a hodža' $\mathrm{s}^{30}$ assurance that the dead live on. In his last letter, he enumerates the mementoes that remain and remind him of his father, mother, and sister, and most important among these are his memories. These he will share with his children, whom he refers to as "half Vlach, half Muslim." ${ }^{31}$ Mirza is guileless in his guarded optimism, and as Nura Bazdulj-Hubijar has said-Mirza is she.

\section{Poetry}

Damir Arsenijević, a critic who focuses specifically on Bosnian women poets, has characterized their writing as providing a liminal space, where difference can be reconsidered in Bosnian society - the "poetry of difference." 32 Others have made such observations about the power of art, and certainly this possibility for dialogue lies at the center of work that goes on in other spheres of Bosnian society that foster peace, justice, and reconciliation - in the NGO sector, in governmental initiatives that promote communication and cooperation across ethnic boundaries, and in the independent media. That art occurs in a "free zone," a special space, whether real or imagined, recommends this particular cultural activity to the very sensitive undertaking of reconsidering the past and building a future in Bosnia and Herzegovina. Women's writing in Bosnia, constituting as it does an "undercurrent" (podstruja) of the mainstream, provides even greater opportunity for the consideration of difference. ${ }^{33}$ 
In various studies of Bosnian women poets who write, as he says, "from the margins," Arsenijević has focused on the poet and arts administrator Ferida Duraković. A poem from her latest collection Locus minoris (2007) demonstrates both stylistically and thematically the challenge that artists and writers have posed in postwar $\mathrm{BiH} .{ }^{34}$ In "To Olena, a girl without anyone, 2004: A dirge" ("Oleni, djevočici bez ikoga, 2004 Tužbalica"), Duraković shocks and awakens, confronts a variety of ills, and, we might hope, inspires readers to action:

\author{
MUŠKARCI MUŠKARCI MUŠKARCI \\ MUŠKARCI OLENA POPIK MUŠKARCI \\ MUŠKARCI \\ MUŠKARCI POLITIKA POLITIKA POLITIKA \\ OLENA \\ TRGOVINA ŽENAMA ŽENAMA TRGOVINA \\ ŽENAMA PROSTITUCIJA PROSTITUCIJA \\ PROSTITUCIJA MUŠKARCI OLENA MUŠKARCI \\ MUŠKARCI PROSTITUCIJA MUŠKARCI \\ MUŠKARCI \\ POLITIKA POPIK POLITIKA POLITIKA POPIK \\ POLITIKA TRGOVINA \\ ŽENAMA TRGOVINA ŽENAMA PROSTITUCIJA \\ PROSTITUCIJA MUŠKARCI MUŠKARCI \\ MUŠKARAC SUPRUGA SESTRA MAJKA KĆER \\ OLENA MUŠKARCI MUŠKARCI MUŠKARCI \\ MUŠKARCI OLENA ISTOK ZAPAD SJEVER JUG \\ ISLAM KRŠĆANSTVO PRAVOSLAVLJE JUDAIZAM \\ ... \\ DVADESET SEDMA JE NOĆ RAMAZANA 2004

\section{MUHAMMEDE} \\ IQRE (84-85)
}

(MEN MEN MEN

MEN OLENA POPIK MEN

MEN

MEN POLITICS POLITICS POLITICS 


\begin{abstract}
OLENA
TRAFFICKING IN WOMEN WOMEN IN TRAFFICKING

WOMEN PROSTITUTION PROSTITUTION

PROSTITUTION MEN OLENA MEN

MEN PROSTITUTION MEN

MEN

POLITICS POPIK POLITICS POLITICS POPIK

POLITICS TRAFFICKING

WOMEN IN TRAFFICKING IN WOMEN PROSTITUTION

PROSTITUTION MEN MEN

MAN WIFE SISTER MOTHER DAUGHTER

OLENA MEN MEN MEN

MEN OLENA EAST WEST NORTH SOUTH

ISLAM CHRISTIANITY ORTHODOXY JUDAISM

IT IS THE TWENTY-SEVENTH NIGHT OF RAMADAN 2004

MUHAMMED

RECITE)
\end{abstract}

In a footnote and key to the poem, the reader learns that in November 2004, on the twenty-seventh day of Ramadan, a Ukranian woman, mother of a three-year-old child, was brought to the hospital in Mostar. The men who left Olena Popik at the doors to the hospital had "made money on her until her last breath. She died of AIDS, syphilis, pneumonia, a drug overdose, and tuberculosis" (85). The poem's structure is exceptional for this collection, and for Duraković's poetry in general. Only the phrase "trafficking in women" reveals a grammatical or syntactical relationship in the text of the poem. Meaning derives, rather, from ungrammatical relationships of contiguity, repetition, and the position of words within the verse or stanza. The poem is anti-aesthetic and violates the classical norms of poetry and language. How else could the poet respond to the violations she addresses: of women (wife, mother, sister, daughter), social mores, and divine law?

Arsenijević explains, for the non-Muslim reader, the significance of this date: "Olena died on the 27th night of Ramadan, known as Lailatul Qadr, the Night of Power, which Muslims celebrate as the night when the Koran was revealed to the Prophet Mohammed. It is also on this night, the belief has it, that God decides the fate of the world for the next year. According to the Koran, the characteristic of the 
night is: 'Peace until the rising of the dawn'" (97:5). ${ }^{35}$ Duraković's coda to the poem implores Muhammed (vocative-Muhammede) to recite (imperative-IQRE) and invokes the Prophet to witness what has occurred, and is occurring. It juxtaposes the purity and unity of the divine teachings against a defiled and fractured world. In Locus minoris, Ferida Duraković mourns death and destruction in Bosnia and Herzegovina during and since the war, and she gives voice to the most vulnerable and marginalized members of society. We will consider her work again, but as an arts administrator whose ideas and decisions with respect to the works of other artists and intellectuals have affected even more directly the growth of civil society.

Another woman poet, of a younger generation, writes within the realm of "difference" that Arsenijević describes. Adisa Bašić has received recognition as a poet and essayist who has captured and conveyed the experience of war and its aftermath as well as the less traumatic but pressing issues of contemporary life in Bosnia and Herzegovina. She writes most often from a decidedly female perspective and she can give voice to emotions or societal concerns that reside at the periphery. Her observations bear significance, however, for the challenges facing all citizens of this bi-partite nation. She was selected to represent $\mathrm{BiH}$ in a U.S. tour sponsored by the State Department. One of the poems she chose to recite called attention to a reality that persists long past the end of hostilities (and of international media attention) in Bosnia:

\author{
Ethnic Cleansing \\ otjerana u grad \\ spasila je život \\ i igle za pletenje- \\ jutrom rano, pored parkirališta \\ na rijetkom ostrvu trave \\ dok pazi stado o kojem sanja \\ ona plete \\ i ledene prolaznike \\ svojim srdačnim pozdravima \\ zbunjuje $^{36}$ \\ (Ethnic Cleansing \\ Driven into the city \\ she saved her life \\ and her knitting needles-
}


early in the morning, next to the parking lot

on a rare island of grass

while she tends the herd of which she dreams

she knits

and embarrasses

the frozen passersby

with her cheery greetings)

Although we might not characterize Bašić's poem as the poet's "cheery greeting," we cannot deny her identification with this victim of ethnic cleansing. She calls to the reader, in Bosnia and beyond, to recognize the plight - and humanity — of these victims, and not to "pass by."

Adisa Bašić has also engaged more "prosaically" with issues confronting women in the arts as well as the role of the arts in contemporary Bosnia and Herzegovina. The magazine Sarajevske sveske (Sarajevo Notebooks) provided her with a forum to express her thoughts on these and other issues when the editor commissioned her to keep a diary for one month and to comment on what she was reading, writing, thinking about, and dreaming about. ${ }^{37}$ Among numerous observations, she laments the difficulties that the woman as poet faces in Bosnian society. Society expects her to be docile, but to be a poet, she must be "crazy." In the course of fulfilling her womanly duties, poetry often takes a back seat. And when this occurs, "society" is relieved, for the woman poet is no longer dangerous (62-63). Commenting more broadly on the arts in $\mathrm{BiH}$, Bašić expresses her disinterest in contemporary theater that addresses universal themes, such as the "dysfunctional" family. For her such themes are a luxury. She feels that the arts must address the more urgent, specifically Bosnian postwar "dysfunctions" (65).

Despite the important role that women poets like Ferida Duraković and Adisa Bašić have played in postwar Bosnia and Herzegovina, which has warranted the specific recognition by literary critics (Arsenijević's "poetry of difference"), not everyone agrees that the war and its aftermath have had a singularly salutary effect on women's contributions to the arts. Certainly extraordinary experiences can spur artistic creation; even on the part of individuals who previously had not felt "called" to the arts. Every war has produced frontline and home-front poets, although critical opinion may vary on whether the expression of authentic experience succeeds aesthetically. So too in Bosnia, some writers and artists still consider formal training 
and familiarity with Western European high culture the more customary prerequisites for the artist and writer.

Another woman poet of the younger generation, Ajla Terzić, questions the appeal of literature which, despite its currency and authenticity, reveals a cultural illiteracy with respect to the "canon," broadly considered. ${ }^{38}$ Aesthetics and the "world of art" reign supreme. We should note, however, that the war and its aftermath inform some of Terzić's writing as well. Her collection It's So Hard for Me to Write (Kako teško pišem, 2004) fits comfortably within the postmodern current of literary stylistics. ${ }^{39}$ Numerous pop-cultural and high-cultural references comingle and reveal a Bosnian reality or problematic that the poet considers against a backdrop of interconnected languages and cultures. Terzić carries out this fragmenting and rearranging of the customary even in the visual presentation of some poems. For instance, in "Cornflake Girl," the verb "I smile" (osmjehujem se) is printed in the shape of a smile, and the words of the phrase "swollen shapes" (nabubreni oblici) are printed with letters that "swell up" in the center of each word (27). Yet, Terzić proves, in her poem "Potočari, Bosnia," that the legacy of the war can call into question our preoccupation with "culture" - whether "high" or "low." 40

Potočari, Bosna
Besmisleno je
brinuti se za sudbinu
Aleca Leamasa
dvoumiti se: zeleni ili crni
čaj
sušiti hlače na radiatoru
sliniti nad kakvom sapunjavom
siroticom
staviti Lucky Day na
repeat

žaliti za propuštenom episodom

Zapadnjog krila

brisati prašinu

propovijedati o oprostu . . .

Da-besmisleno je sve to

kada znam da

postoji 
žena koja je držala

ljudske zube

u rukama i rekla:

Da, ovo je moje dijete (43)

(Potočari, Bosnia

It is senseless

to worry about the fate

of Alec Leamas ${ }^{41}$

to ponder: green or black

tea

to dry pants on the radiator

to whimper over some "soap opera"

orphan girl

to put Lucky Day

on "repeat"

to mourn a missed episode

of West Wing

to wipe away dust

to preach absolution

Yes-it is all senseless

when I know that

there exists

a woman who held

human teeth

in her hands and said

Yes, this is my child)

Despite their differences (e.g., of artistic circle, "schooling," or generation), the women writers and poets represented here provide, all the same, an open forum for acknowledging and considering the effects of the war and its aftermath. They invoke remembrance and reconsideration - necessary in pursuit of the "truth" that precedes reconciliation and facilitates recovery. 


\section{Visual Arts}

It is in the area of the visual arts (and no doubt a result of their greater crosscultural accessibility) that women artists and filmmakers have received the greatest recognition beyond the borders of Bosnia and Herzegovina. In particular, the awards won in recent years by films such as Grbavica and Snijeg (Snow) have brought worldwide attention to the female directors of the films and, through their visualizations, to some of the pressing concerns of postwar Bosnia. Yet, women artists began immediately after the end of the war in 1995 to contribute to the recovery effort. Through their various media, they gave representation to catastrophic events and voice to survivors who desperately needed advocacy. Most significant for the growth of civil society, women, through their art, have encouraged public discourse or debate on matters that to some might have seemed less compelling than the country's urgent need for material reconstruction.

\section{Sculpture / Installations / Performance Art}

For Alma Suljević, a sculptor and instructor at Sarajevo's Academy of Fine Arts (Akademija likovnih umjetnosti), the war led to unconventional choices. Although she maintains that she never wanted to join the Bosnian army, she felt compelled, nonetheless, to defend her besieged city. ${ }^{42}$ What she experienced as a citizen of Sarajevo and as a soldier transformed her art as well. She now rejects pure aestheticism: "Art must take the position of doctor of society. We must recognize our problems. We must tell of its cancers. We must show ... people how they can . . . make . . . our society better. I mean to make it healthy." ${ }^{43}$ Formerly apolitical, her artwork now deals exclusively with the war and its aftermath. She combines her work as a de-miner with the artistic genres of installation and performance art.

Suljević's mission to eradicate landmines remains relevant more than ten years after the end of the war. The government has not yet met treaty commitments concerning de-mining, and it is estimated that two hundred twenty thousand landmines remain over an area of approximately six hundred square miles. ${ }^{44}$ To raise public awareness, Suljević has constructed jewel boxes that open to display defused mines. ${ }^{45}$ They not only warn against the danger that lies within the country's natural beauty; they also lament the war that transformed Bosnia into a "Pandora's box." An installation, also on the theme of landmines, invites guests to walk upon a map of Bosnia, where minefields have been identified, and to share their thoughts on the theme and their experiences. They can purchase lithographs related to the installation, and 
proceeds are donated to de-mining efforts. ${ }^{46}$ In a work of performance art, Suljević has visited outdoor markets to distribute brochures on the danger of landmines, and she has sold bags of earth from de-mined fields; again in an effort to raise funds for de-mining ${ }^{47}$ Alma Suljević contributes directly, through de-mining and fund-raising, to the physical recovery of Bosnia and Herzegovina. And as an artist, she strives to increase public awareness of the continuing threat of landmines. The aestheticism of the academy has given way, without reservation, to engaged art.

The war and its aftermath have affected the art world in numerous ways - some predictable and some unforeseen. The total or partial destruction of municipal buildings in Sarajevo reduced or eliminated public space dedicated to the exhibition and creation of the works of visual artists (an issue we will return to below). Artists and exhibition curators reacted by taking art to the public square, with the serendipitous result of engaging many who otherwise would not enter a museum or studio, but who cannot help but participate in an artistic event that literally crosses their path. ${ }^{48}$ The limited opportunity for artists in a war-torn country is one of several reasons for the emigration of a number of high-profile artists and of the chosen identification of some with the "migrant." Two successful artists, both working in multimedia, now claim dual "citizenship": Maja Bajević, whose works identify her "origin" as Paris and Sarajevo, and Danica Dakić, who claims residence in both Sarajevo and Düsseldorf (in both cases, the cities are cited in varying order). Although $\mathrm{BiH}$ can no longer claim either artist as wholly Bosnian, these women have brought an international dimension to their art, and they continue to call attention to the danger of nationalism, the question of identity, and the particular plight of their birthplace. ${ }^{49}$

A work of public art that the citizens of Sarajevo experienced, perhaps daily, after the war was Danica Dakić's Witness (1998). Before the return of the bust of Nobel laureate Ivo Andrić to its plinth — it had been removed for safe-keeping during the siege, like many other statues of writers exhibited in a city park-Dakić mounted in its place a video of a disembodied hand encased in glass (fig. 1) ${ }^{50}$ Passersby would hear the sound of a typewriter. The sound caught their attention and the "writing hand" had the potential to raise such questions as "Who is writing history?" and "Who 'owns' 'Yugoslav' literature and 'Yugoslav' writers?"

In 2006, both these artists of international standing, who highlight in their art their multiple identities, took part in an international exhibition of art from postcommunist Eastern Europe. The contribution to Eastern Neighbors from Bosnia and Herzegovina carried special significance. The curator of the exhibition, Dunja Blažević, had the specific intent to mount the first joint exhibition between the National Gallery of Art of Bosnia and Herzegovina in Sarajevo and the Museum 


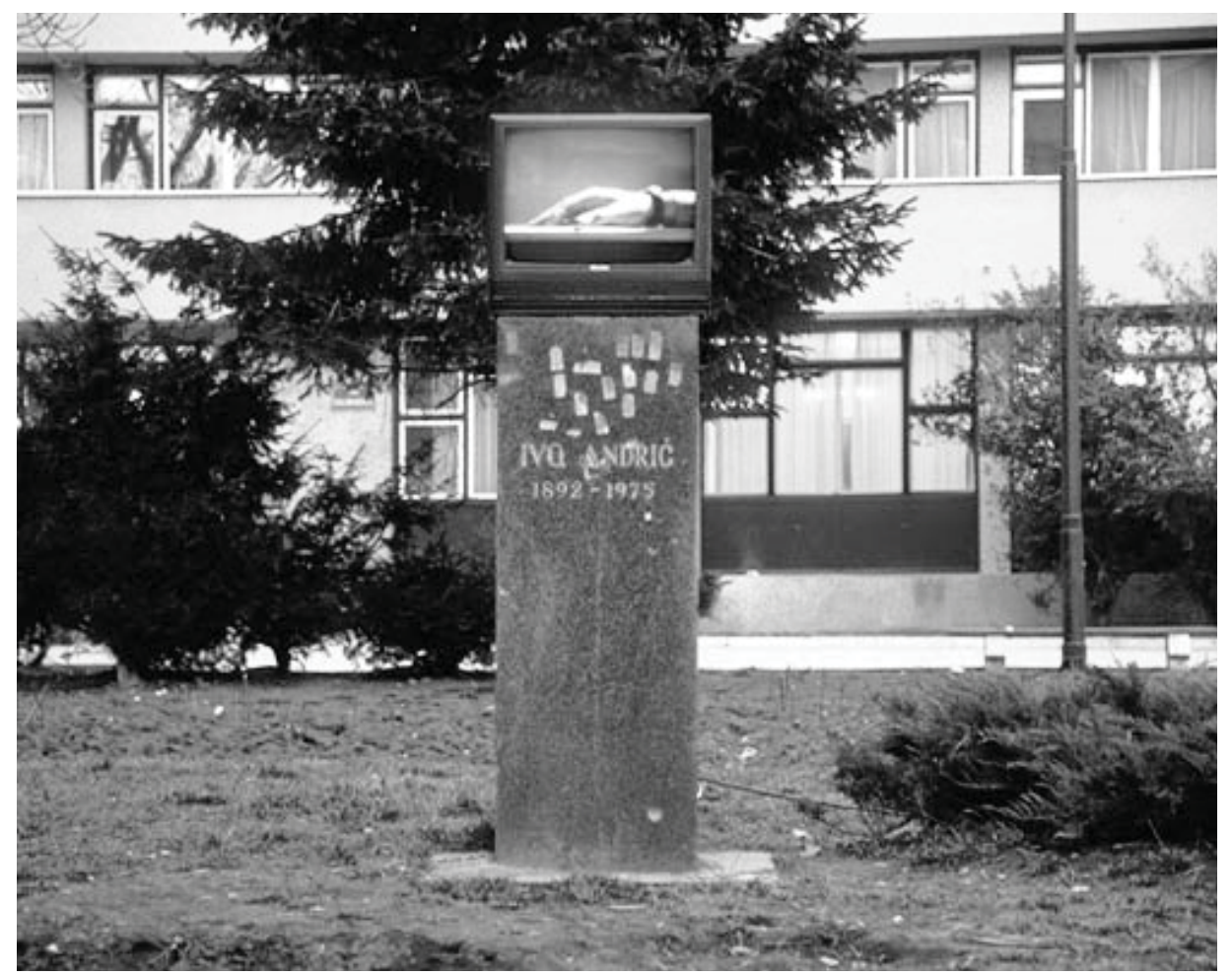

Figure 1. Witness, Danica Dakić, 1998

of Contemporary Art of the Serb Republic in Banja Luka. ${ }^{51}$ The contributing artists represented all three major ethnic groups in Bosnia and Herzegovina. Dakić's and Bajević's joint video installation I Love-I Don't Love explores the relationship of language to identity. The individual exhibits addressed, for their Bosnian audience, a variety of postwar and postcommunist concerns. The joint exhibition that traveled abroad symbolized an imagined future where the entities, the Federation and the Serb Republic, would function in harmony, or even more optimistically, a time when Bosnia and Herzegovina would again be united. Although the audience for this exhibition was former Yugoslavia's Western neighbors, the collaboration of artists and galleries from the two entities and major ethnic groups contributed to the growth of cultural connections that can transcend ethnicity.

Like Danica Dakić, Maja Bajević exhibits her work primarily to an international audience (which now includes, of course, other successor states of Yugoslavia). The 


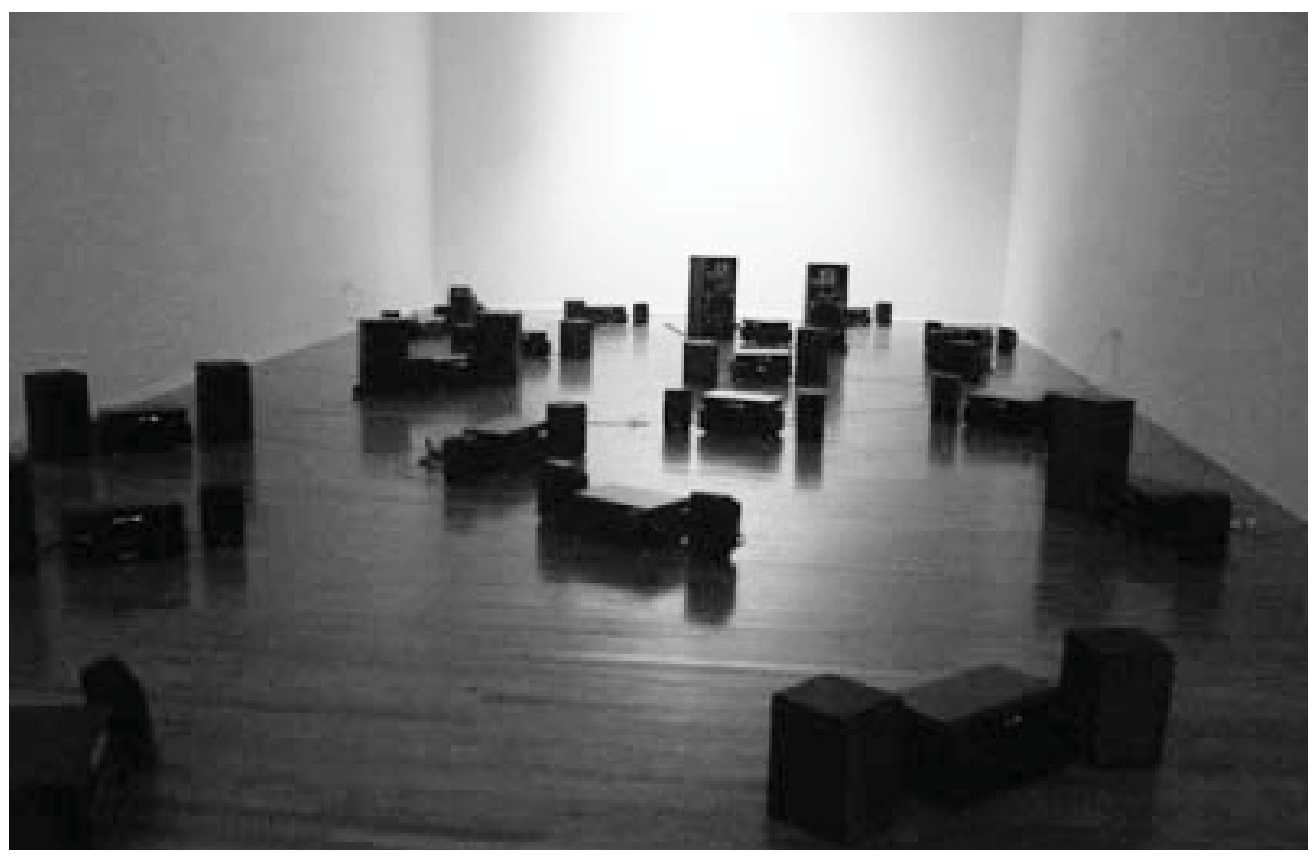

Figure 2. Avanti popolo, Maja Bajević, 2002/05

Sound installation, hi-fi system, sensors.

Courtesy of the artist and Galerie Peter Kilchmann, Zurich

socially engaged themes of her artwork carry universal significance, but they resonate quite specifically with the history of Bosnia and Herzegovina. Such is the case with the sound installation Avanti popolo (fig. 2). The title is derived from the Italian revolutionary song of that name, and the installation includes national anthems and songs that have had ambivalent effects. Such music has incited national unity; yet the dangers of nationalism, well recognized historically, became tragically apparent again in former Yugoslavia in the 1990s. Resurgent folk music - for instance, the ancient Croatian ganga and rere or the fusion genre of Serbian "turbo folk"- exercised the well-known power of music to excite and incite. Bajević refers to her installation as a "minefield of songs." 52

In 2006, Bosnians and others had the opportunity to experience a retrospective of Maja Bajević's works and installations, which have addressed on the international stage the recent history and continuing concerns of $\mathrm{BiH}$. The exhibition, housed on 

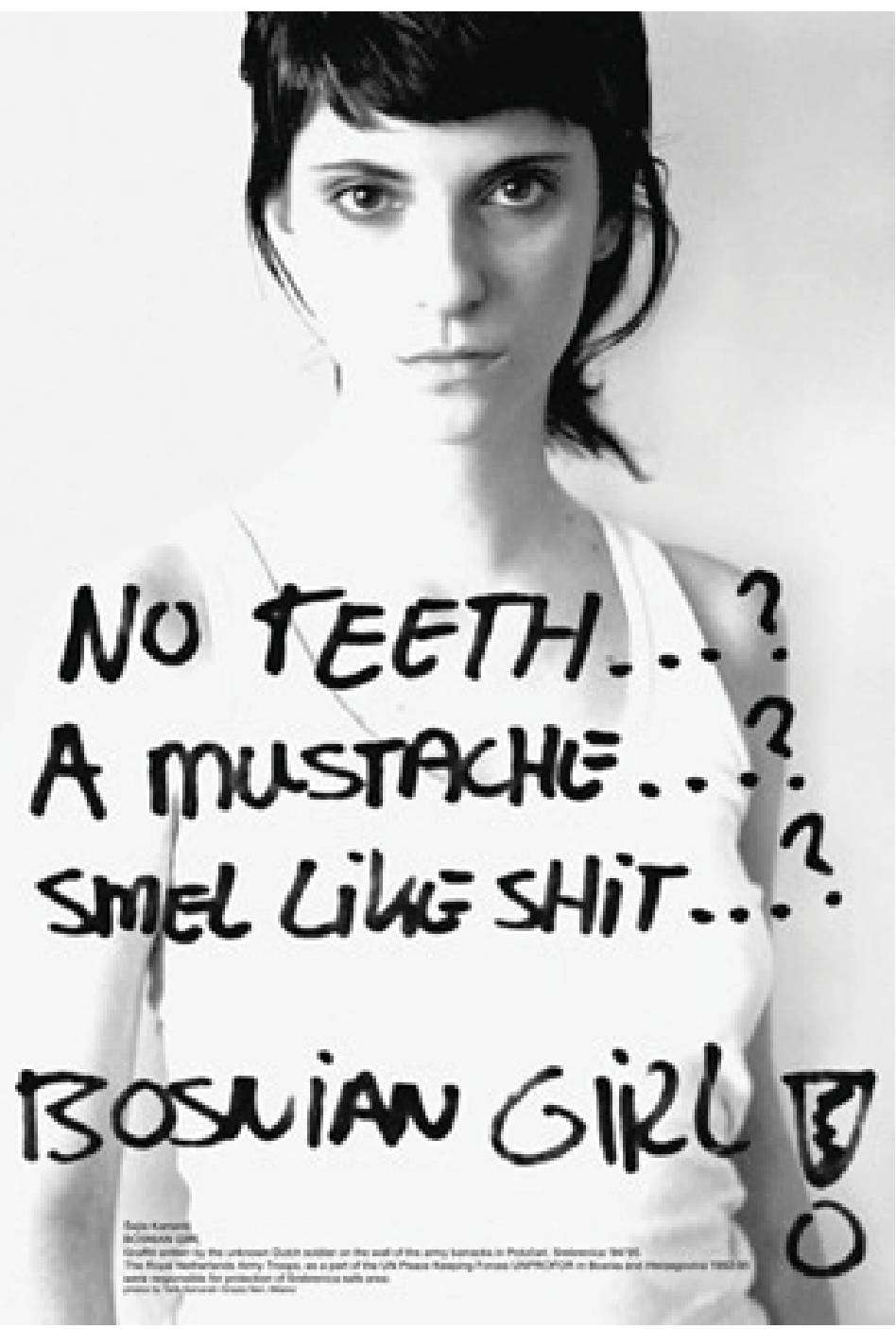

Figure 3. Bosnian Girl, Šejla Kamerić, 2003 
three floors of the National Gallery of Art (Umjetnička galerija Bosne i Hercegovine) bore the title Home Again. ${ }^{53}$

The artist whose work has received more notice internationally — within and beyond the art world - than any of the engaged women artists profiled here is Šejla Kamerić, and this for the poster Bosnian Girl (fig. 3).

This poster provoked discussion, and argument, when it received broad exposure on the streets of Sarajevo in July 2003. Numerous copies hung along the route taken by mourners on the eighth anniversary of the massacre at Srebrenica (11 July 1995) as they made their way to Potočari, near Srebrenica, to bury the exhumed remains of their loved ones.

Bosnian Girl, now as then, continues to elicit a variety of responses, and it is open to troublesome misinterpretation. The graffiti that covers the photograph of an attractive young woman, comes from the barracks of a contingent of the Royal Netherlands Army, whose mission it was to protect the inhabitants and refugees of the safe area of Srebrenica. The initiated viewer of the poster cannot misinterpret the disdain that at least one Dutch soldier felt for the Bosniaks under his protection. And the initiated will perceive as well the intended ambivalence. The Western soldier experiences repugnance toward people who have been ravaged by war, many displaced and suffering for want of adequate food and shelter, and yet he cannot spell - or conjugate-English correctly. And further, his ungrammatical script is imposed on the photograph of a "typical" Bosnian girl - in peace time.

Kamerić has insisted on her poster's defiance of cultural stereotypes, but the reception of her work has often defied her intent. Elissa Helms includes Bosnian Girl in her analysis of the image of women in Bosnia and Herzegovina and cites an alternative interpretation within the "urban/rural divide" that characterizes other aspects of Bosnian culture. ${ }^{54}$ This "girl" is, in fact, not any Bosnian girl. The photograph is of the artist herself, a cosmopolitan Sarajevan artist. Critics complained that the artist should have countered the ugly Dutch slur with the photograph of a "typical" lovely girl of rural Bosnia. Others perceived in Kamerić's poster something perhaps worse - the condescension of an urban elite toward her fellow, and sister, Bosniaks. I have encountered further criticism of the work- that Kamerić would choose her own photograph smacks of self-promotion. Then there is the unfortunate response of the uninitiated viewer, who does not know of or, sadly, remember the Srebrenica massacre, and who fails to see the inherent tension or irony. Bosnian Girl is only one work among a body of Šejla Kamerić's artwork that confronts the war and its legacy. ${ }^{55}$ This one poster deserves particular attention, however, as an example of another figurative minefield in a society as diverse and challenged as postwar Bosnia and Herzegovina. 


\section{Film}

In the visual arts, it is arguably engaged women filmmakers and directors who have made the greatest strides for women artists in postwar Bosnia. At the same time, they have, again arguably, achieved the greatest success in drawing international attention to the issues surrounding the Bosnian War and the current challenge of recovery and reconciliation. Two of these women, Jasmila Žbanić and Aida Begić, have already received international acclaim for films they directed that depict the plight of women who survived the war.

Jasmila Žbanić wrote and directed GrbavicalEsma's Secret (2006), which describes the plight of a victim of wartime rape and the daughter she conceived in violence. Žbanić and the lead actress Mirjana Karanović received numerous awards, including the Golden Bear, given to Žbanić at the 2006 Berlin International Film Festival. Grbavica refocused international attention on the aftermath of the Bosnian War and on rape as a war crime, which in many places still in Bosnia will not be discussed. Dina Iordanova identifies Grbavica, along with Žbanić's episode "Birthday" in Lost and Found (2005), as examples of what she terms "hushed histories." These she defines as "stories evolving at the peripheries of a peripheral region, narratives of patriarchal dominance and subplots of suppression that do not quite line up to fit into the rough outline but remain hidden, forgotten, relegated to oblivion." ${ }^{56}$ She considers such hushed histories a characteristic of women directors in Southeastern Europe. The hidden story of "Birthday" comes from Mostar and follows two girls born on the same day, 9 November 1993, when Croatian forces destroyed the iconic sixteenth-century Old Bridge, and who were raised in silence and isolation on their respective (Bosniak and Croatian) sides of the Neretva River. Both films have contributed to postwar recovery, breaking the silence that may surround the victims of wartime rape, and the postwar generation that in many cases is being raised in ignorance of the events of the 1990s in Bosnia and Herzegovina. ${ }^{57}$

Žbanić's most recent film is entitled On the Path (Na putu, 2010), and it was also nominated for the Golden Bear at the 60th Berlin International Film Festival. The film addresses her most "hushed" theme to date. Luna and Amar both work at the Sarajevo Airport — she is a flight attendant, and he an air traffic controller. Amar fought with the Bosnian Army and both lost their families in the war, but they have found happiness with each other. The film chronicles the effects upon their relationship of Amar's problem with alcohol and their inability to conceive a child. Amar is eventually suspended from his job due to his drinking, and attempts to overcome his dependency through traditional therapies fail. Quite by chance Amar 
meets a fellow soldier from the war, Bahrija, who has become a devout Muslim. Bahrija takes Amar to the mosque and encourages his conversion to strict Islamic practices. Amar renounces alcohol, but he also embraces a form of religious practice (Wahhbism) that is foreign to Luna (and Bosnia) and leaves the future of their relationship in doubt.

Jasmila Žbanić's films provoke public discourse about the war and its aftermath and thwart attempts to stifle a consideration of the past. Invoking a reconsideration of the events of the war, they contribute to the quest for the truth that can facilitate reconciliation. And with On the Path, Žbanić confronts the question that relatively few raise publicly today in Bosnia - the path forward for Bosnians of Muslim heritage. Should secular Bosniaks reclaim their religious heritage? If so, should they practice again the liberal Sufi Islam of the Ottomans or embrace the Wahhabism of the Mujahideen fighters who came to their aid during the war, and which informs the continuing philanthropy from the Middle East (and in particular from Saudi Arabia)?

In its treatment of an easily forgotten or ignored segment of Bosnian societyrural women survivors-Aida Begić's award-winning Snow (Snijeg, 2008) qualifies as yet another "hushed history." 58 The village of Slavno (in Bosnian, the name means "famous" or "marvelous") stands for many isolated rural enclaves where, after the war ended in 1995, women and children remained, not knowing the fate of their male loved ones. Theirs is now a woman's world, where women must find a way forward to support themselves and their families. They must also preserve memory and maintain hope, all the while coming to terms with their own grief and suffering.

The protagonist of the film, Alma, is a young widow whose husband disappeared along with all the men and boys of the village. Only an elderly imam (religious leader) and a young boy somehow survived. The question of her decision to take the headscarf is never openly addressed in the film. But the viewer gathers that it has been a conscious choice. When late one night Alma retrieves photographs from a box under her bed, we see from the side the images of the past. One is of a couple. None of the women wears a headscarf. The viewer assumes that Alma is one of the numerous widows of eastern Bosnia who have found comfort in the (perhaps) newfound belief and practices of their hereditary faith. Some of the most beautiful scenes of the film relate to these practices-Alma walking along the paths of her village, in reality or dream, the folds of her varying scarves moving with the wind, or her performing of the abdest, the ritual washing, before worship. Yet, with the 
exception of the "grandmother" of the village and another older woman, Alma is the only widow to have taken the veil.

The complicating events of the film involve the widows' attempts to provide a livelihood for themselves and the children by selling the various jams and preserves that they prepare from their harvest and the visit of a Bosnian Serb, who comes to Slavno as a representative of a foreign firm that is attempting to buy the village and surrounding land. The women struggle with both their decision about the land and their complicated reaction, to say the least, to the intrusion of a Bosnian Serb into their stable (if not always harmonious) women's enclave. When, during his second visit, the Serb is stranded by a storm and must spend the night in Slavno, the extended contact with the women and the ensuing confrontation lead to revelations about the fate of their loved ones and the dramatic climax of the film.

Begic identifies the main themes of her film as the freedom to choose and the confrontation with the past. A slice of the women of Slavno's life in the aftermath gives visual representation to small stories of recovery and individual paths toward the discovery of the truth - that first step on the path toward reconciliation. Begic affirms the significance of such stories:

I think that a return to the past need not be something regressive - to remember some horrid things, something that will pull us into the past . . . from time to time all of us must confront the lies of the past so that we can simply keep on living. As long as the war or its consequences are present in our lives, they will be present in art as well. As long as we feel that something has gone wrong, then that will be thematicized in art. Reality is connected to the past. It is impossible to make a film here about anything and avoid it, because it so much defines us, so much colors us, and hinders us so much as well. ${ }^{59}$

That her film honors the personal odysseys of survivors who face the ravages of history Begić makes clear in her director's notes, which she prefaces with the proverb, "Snow doesn't fall to cover the hill, but so that each little animal can leave its trace" (Snijeg ne pada da prekrije brijeg, već da svaka zvjerka svoj trag ostavi) ${ }^{60}$ This proverb adds another layer of significance to the motif of snow. In the film, the Bosnian Serb who is attempting to convince Alma's mother-in-law to sell her plot of land, the largest in the village, poses the question that is often directed toward the elderly, "And what will you do when the snow falls?" When the snow falls in Snow, the women indeed face a turning point in their lives. They learn of the fate of their men. In response they set out en masse to retrieve their remains. They ensure the future "trace" of their loved ones (their graves), and then, it is implied, they move on in life in various ways. As Aida Begić has stated, she will continue to make films 
that confront the past, that give image and voice to those who might be overlooked (particularly women) in what she considers a misguided or facile rush to move on. ${ }^{61}$ Truth provides the foundation for reconciliation and recovery.

With the international acclaim - and distribution - of their feature films, Jasmila Žbanić and Aida Begić have established the reputation of women directors and filmmakers in Bosnia and Herzegovina. Other women have gained recognition on a smaller scale and in the field of independent documentary film, which by definition provides greater access to women filmmakers in general. ${ }^{62}$ Danijela Majstorović, a professor at the University of Banja Luka (Serb Republic), has produced two films that address the plight of vulnerable women in Bosnia. She conceived the idea of her film on human trafficking, Counterpoint for Her (Kontrapunkt za nju, 2004) after learning that a report by the U.S. House of Representatives in 2003 identified Bosnia as the first stop for trafficked women in Southeastern Europe. Her next film, Dream Job (Posao snova, 2005), chronicles the fate of young girls lured by "show business" in a society of limited opportunities for women. Both films reveal the particular effect on women in Bosnia of postcommunist and postconflict social and economic instability. They indict government and law enforcement for their unwillingness, or inability, to thwart criminal activity or to provide adequate training, education, and protection for the most vulnerable members of society. Majstorović states that in conjunction with her Center for Social and Cultural Repair, she will continue to produce documentaries: "We want to make docs for . . . marginalized groups and we want to at least provoke . . . society." ${ }^{63}$ Women directors and filmmakers are closing the gender gap in this realm of the visual arts in $\mathrm{BiH}$. Even more important for this fragile democracy, their films challenge social and governmental structures and thereby contribute to the growth of civil society.

\section{Organizing in Their Own Behalf}

It is evident that the work of these women writers, artists, directors, and filmmakers constitutes, in essence, "social action." Yet, women in the art world have mobilized and taken action beyond their own engaged art and in their own defense, to address a concern that threatens their ability to create. A declaration, sent in 2003 to the male ministers of culture and signed by a number of the artists and directors profiled above, began thus: "How to solve the problem of the basic conditions for work and creativity (work space, the means to work) if you are an artist, a designer, a director ... ? And if you live in Sarajevo in 2003? There is no way, because you 
are a woman, because you are a woman with local and international professional references, because behind you there stands no party, no nation, no influential man - a father or a spouse." ${ }^{64}$

Alma Suljević, Šejla Kamerić, Jasmila Žbanić, and others protested the lamentable situation for women artists in Bosnia- "sexual, professional, and political discrimination." ${ }^{65}$ Topping the artists' complaints was the lack of work space, a benefit that studio artists in socialist Yugoslavia received through well-known governmentfunded centers for the arts. However, in 2003, eight years after the end of the war, no woman had managed to obtain funded work space, and the artists complained as well of a lack of institutions to which they might turn in their pursuit of a studio. ${ }^{66}$ This type of grass-roots action characterizes more the work of NGOs. In this case, however, Bosnian women artists, whose engaged art fosters the pursuit of truth and encourages recovery efforts, have taken on the additional role of (necessarily selfinterested) civic activist. Their work in this vein dovetails with that of arts administrators, who decide, as directors and curators, which exhibitions will be mounted and who will be provided space and/or financial support.

\section{Arts Management}

Since the war, women are seeking not simply greater representation in all public spheres, but positions of authority within these spheres, as leaders and owners in business, as editors in journalism, as heads of NGOs, as influential politicians. Women in the arts evidence these aspirations as well. They are seeking to be funded and to receive work space through political action. And they have risen, in some organizations that support the arts, to positions of leadership.

Jelka Kebo directs the government-run Center for Culture (Centar za Kulturu) in Mostar. Unfortunately, the postwar situation in this famous "city of the bridge" (in Bosnian/Croatian/Serbian, most means "bridge") belies its modern history as a symbol of interethnic harmony. As in Sarajevo during the Yugoslav era, one could find ethnic neighborhoods in Mostar where the residents were primarily ethnic Croats or Bosniaks. However, the city identified with its relatively urban center, where the various ethnicities commingled, worked together, and often intermarried. ${ }^{67}$ At the beginning of the war, the primarily ethnic Croat and Bosniak inhabitants fought together against the Bosnian Serb forces. Later, however, they fought each other, in a particularly lethal and close-range conflict that led to the destruction of the emblematic sixteenth-century bridge. Inhabitants took sides and the city became 
ethnically divided. Not much has changed. The reconstructed bridge and surrounding buildings grace again the Bosniak Old Town, but there is little else of economic significance in the eastern part of the city. As a young Bosniak woman, who along with her family runs a café near the bridge, told me: "They got the factories and the university. ${ }^{68}$ What did we get? The Old Town and the bus station. Everything is separate. Nothing has changed." This woman went on to explain that during the winter, when there are no tourists and the Old Town is deserted, she attends medical school in the Muslim-majority city of Zenica. ${ }^{69}$ She intends to get her degree, but does not expect to marry or have children. She has no interest in the life that would be prescribed for her as a married woman - of domesticity and restriction to the private life of the home. Her rejection of a social conservatism that (postwar?) defines her family stands in sharp contrast to both her impressive goal of earning a medical degree and the trendy internet café she runs with her family just off the famous bridge. It is a story we might take as emblematic of the tensions that still define Mostar, both within and across ethnicities.

This is the environment in Mostar in which Jelka Kebo works. She is an ethnic Croat; her husband, recently deceased, was an artist of Muslim heritage. Her elder son and husband fought in the war, and the son died shortly thereafter. She said that she might be defeated and bitter. But she feels an obligation to her remaining son to work for reconciliation, to give him a model of hope. ${ }^{70}$ Furthermore, she chooses to work in the arts because it is the only arena, in her view, where all the ethnicities work together harmoniously for a common purpose. She considers art in the broad sense to be the healthiest sphere in Bosnian society, a space where the country can begin to recover. She expresses this conviction at every opportunity. In fact, although her organization is government run, she is quoted on the homepage of a Belgian NGO, Kultura Balkanica: "Culture is the strongest factor of integration that we should use in breaking down the barriers that separate us." ${ }^{\prime 71}$ Kebo took this leadership role after the war. She has expressed in other interviews her growing sense of empowerment during and since the war. ${ }^{72}$

Ferida Duraković, in Sarajevo, would identify herself first and foremost as a poet. She has been publishing poetry since the $1970 \mathrm{~s} .{ }^{73}$ Her collections from before the war addressed love and relationship from an identifiable female perspective, and they include poetry addressed to a juvenile audience. As with many artists, the war affected her writing profoundly. She wrote the war. And since the war, her poetry addresses to a much greater extent the role of the mother (which she experienced for the first time during the war) and the fate of children. These overriding concerns are inextricably connected to the fate of Bosnia in the aftermath. This is Duraković's 
primary concern, and yet, it is her job as general secretary of the PEN Centre Bosnia and Herzegovina that consumes most of her time and energy.

A recent publication of the PEN Centre, edited by Ferida Duraković and Marina Trumić, represents well the organization's efforts to address residual ethnic tensions and to reflect upon its own efficacy. Literature and the Challenges of Politics (Književnost i izazovi politike 2008) presents the transcripts of a series of "conversations" held in 2006 and 2007 (funded by the Heinrich Böll Foundation, the Open Society Fund Bosnia and Herzegovina, and the Ministry of Culture and Sport of the Federation of Bosnia and Herzegovina) on such topics as "Religious Organizations and Freedom of Speech" ("Vjerske zajednice i sloboda govora"), "The Ranges and Boundaries of Public Dialog-What One Dares and What One Dares Not to Say in Public" ("Dometi i granice javnog dijaloga—Šta se smije, a šta ne smije javno reći"), and "To Write About the War-The Experiences of Reality, Imagination, Morality, and Politics" ("Pisati o ratu-Iskušenja stvarnosti, imaginacije, morala i politike"). Both the series and the publication that followed it challenged and countered "what one dares not to say in public." 74

Women have played a significant role in these Sarajevo discussions to date. Although women number only ten among the seventy members of the PEN Centre, they contributed significantly (and disproportionately) to the planning and execution of these events and related publications. In addition to editing the proceedings, women members of the Centre suggested approximately half of the ten topics that were addressed in these open forums. Following these events, Duraković conceived a proposal for funding (submitted to the Open Society Fund and the Heinrich Böll Foundation) entitled "Where Now After Independence-Public Discourse and the Future of BiH" ("Kamo dalje od slobode_-Javna riječ i budućnost BiH"). She circulated a letter among members and solicited suggestions for themes relevant to this initiative. Women members contributed half the fourteen topics chosen, including, for example, The role of minorities in the formation of public opinion (gender, marginalized groups and alternative organizations), Can a free press increase freedom in society? and Is the public forum, for intellectuals, what the market is for the economy. ${ }^{75}$ As with the artists' declaration demanding better conditions and support for artists, the activities of Ferida Duraković and other female members of the PEN Centre Bosnia and Herzegovina range beyond the free zone that their art provides for the public dialogue that is requisite in civil society. They engage in direct social action as well. 


\section{Curation}

A consideration of the activities of arts administrators like Ferida Duraković or Jelka Kebo demonstrates that it is not only the original work of artists that can provide opportunities for recovery, reconciliation, and the growth of civil society. Those engaged at various levels of organization and activity in the art world, and not only the artists themselves, acknowledge with their professional decisions a belief in the power of art, new and preserved, to celebrate humanity and, perhaps, to bridge differences.

We cannot turn to a consideration of curatorial decisions at the National Museum in Sarajevo (Zemaljski Muzej) ${ }^{76}$ without recognizing the valorous efforts of curators and other employees during the siege of Sarajevo. Because some staff members of the museum had come from other republics (Serbia or Croatia) to work in their specialty in Sarajevo but chose when war broke out to return to one of these successor states, and because most able-bodied men joined the Bosnian army or other defense forces, those left to preserve and protect the holdings of the museum were primarily women. They strove, with great commitment and courage, to work their shifts (usually every other day), debilitated by hunger and stress, and often under sniper fire. They arranged the evacuation of some exhibits, moved others for safekeeping on the grounds of the museum, and struggled to protect the buildings of the museum complex (e.g., by lugging heavy bags of wet dirt to cover exposed windows) ${ }^{77}$ Their story calls to mind similar heroic actions during the siege, like the evacuation of some of the holdings of the National and University Library before it was shelled and destroyed by fire (25-26 August 1992) and the rescue and preservation of the famous Sarajevo Haggadah from the same National Museum. ${ }^{78}$ Dr. Đenana Buturović has since written a history of the National Museum before and during the Bosnian War, and colleagues and academics in related fields have acknowledged their contribution to the survival of the museum. ${ }^{79}$ The exhibitions that today speak to the shared material culture of Bosnia and Herzegovina would not be possible without the sacrifices these women creators made to preserve their shared heritage.

An outstanding example of the critical choices the primarily women curators have made since the war to utilize the museum's holdings to consider the critical questions of history and identity in Bosnia and Herzegovina is the exhibition Which Shirt Is Mine? (Koja je moja košulja?). In a series of display cases, the curators and preparators of the Department of Material Culture have chosen a beautiful array 
of women's shirts, which were the basic woman's garment (the dalmatica), dating from Roman times, throughout the Western Balkans (fig. 4).

The distinguishing factors that account for the major differences in style and fabric derive from region and class, rather than religion. The more subtle differences, which did distinguish women of varying faiths, over time, the viewer will find in the exhibition catalogue, not in the display. This was the curators' and preparators' conscious choice. A visitor to this stunning exhibition cannot help but perceive the continuity of culture over time in Bosnia and Herzegovina and sense the shared experience of migration (the Slavs), empire (the Ottoman incursion and the Austro-Hungarian Annexation), and place (the more rugged shirts of the women inhabiting the Dinaric mountain range). This stalwart group of women contributed to the survival of the National Museum and of their cultural heritage. With equal

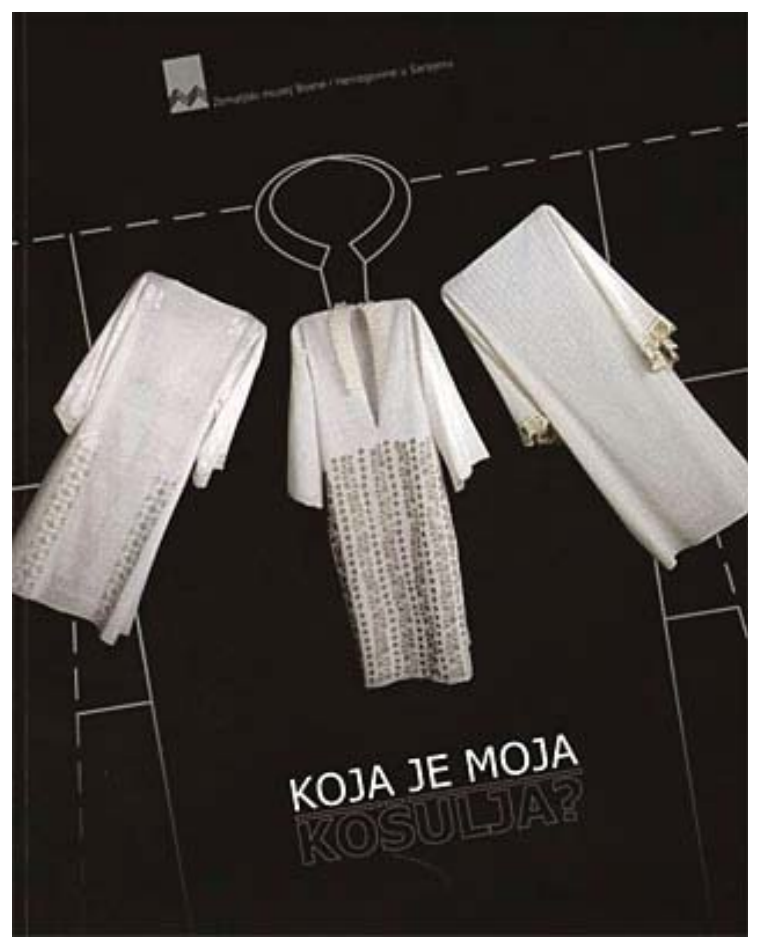

Figure 4. Catalogue from Which Shirt Is Mine? 
determination they now provoke serious and open reconsideration of the past and thereby contribute as well to recovery and reconciliation.

As demonstrated with her curation of the exhibition Eastern Neighbors, and the contributions of artists Maja Bajević and Danica Dakić described above, the director of the Sarajevo Centre for Contemporary Art (SCCA), Dunja Blažević, supports a newly engaged art, and she has quite consciously expressed and publicized its goals: "In no country in Europe is cultural policy more important than in Bosnia and Herzegovina. Culture is both the cause and the solution to its problems. Cultural arguments were used to divide the country, yet culture might be able to bring the people back together again through initiating cultural programs that increase mutual understanding and respect." 80 And further, "This diagnosis of the symptoms of the disease, as well as its cure, can be applied to all parts of the former Yugoslavia. The disease is called: the manipulation of culture, art, religion and media by the nationalist elite. The cure is called: the decontamination of culture." $" 81$

Blažević speaks specifically about the role of her particular area of expertise, contemporary art: "On the scene is a contemporary art that thinks about and reflects on the time in which it lives, open to communication with the outside world, with others. This is art that uses and explores new media and art forms that pose questions that deal with social traumas, that demystifies traditional notions of art as well as collective ideological patterns and truths. . . . This 'other art,' with its practiceits method of organization, its working strategies and spheres of interest-has the potential to change the dominant cultural models and thought matrices. To make this potential visible and effective is the task and the goal of the new and emerging cultural subjects in the region." ${ }^{2}$

When she writes of the potential of high culture to effect change, Dunja Blažević implies a degree of uncertainty as to the realization of those stated goals. Yet, she has demonstrated, with her influence as director of the SCCA, what might be possible. As she openly states: "The SCCA gives support to those art projects which publicly and openly raise issues related to our time and start a direct dialogue with citizens in a new and untraditional way, both in form and in content." ${ }^{83}$ Testimony to this commitment were the public debates that the SCCA held in connection with a public installation by the artists Kurt and Plasto in the fall of 2001, which questioned who actually owns public spaces - this in connection with the delayed return of the busts of "Yugoslav" writers on Liberation Square that had been removed during the war. The stunning and salutary result of these debates was a unanimous decision by the fifty invitees, public figures representing various fields, to return the busts without seeking official permission. The SCCA undertook the realization of this 
decision, and in just over one month from the day of the debates, the busts were back on their pedestals. ${ }^{84}$

The SCCA proceeded to sponsor a related initiative, De/construction of Monument (2004-06), which involved an array of public actions and installations, seminars, and exhibitions in Sarajevo and also, in collaboration with other arts organizations, in Mostar, the cultural center of ethnic Croats in Herzegovina; in Banja Luka, the capital of the Serb Republic; and, internationally, in Kosovo. During a seminar held in conjunction with the initiative, at the National Gallery and the Academy of Fine Arts in Sarajevo in July 2004, the SCCA sponsored the artist Gordana Anđelić-Galić's banner, which hung over Ferhadija Street in the center of the city, and read: "The number of monuments erected to glorify one person is in direct proportion with the lack of individual freedoms." It was a provocative statement intended to initiate debate over the symbolic use of public spaces. The SCCA also worked in connection with De/construction of Monument with organizations in Banja Luka, such as the Center for Informative Decontamination that publishes the magazine Noise (Buka) and produces an antinationalist program for a local TV station, "Alternative TV." The initiative received its highest level of international attention in 2005, with the dedication of a statue in Mostar that was a result of SCCA's collaboration with Urban Movement, an NGO in Mostar. The unveiling of a statue of the Kung-Fu hero Bruce Lee in the center of Mostar (fig. 5) gave rise to considerable debate, despite its stated purpose: "The Bruce Lee monument initiative represents an attempt for the public spaces to regain their meaning, and at the same time to question the significance of monuments and symbols, the old and the new ones as well." 85

Do all who experience the statue celebrate the universal appeal of the values expressed by this multi-ethnic (Chinese-American) cult hero? Or might one also lament the impossibility of paying homage publicly in Mostar to all the fallen heroes of the recent war? Despite the varying reception that the statue might invoke, it enlivened the debate over the ownership of public spaces and commemoration. Dunja Blažević's role in these SCCA initiatives proves the influence of arts administrators in $\mathrm{BiH}$ today - so many of them women. And like the women artists profiled above who petitioned the government for equal support in acquiring studio space, arts administrators can resolve to take action.

Other curators have sought, in the spirit of the international exhibition Eastern Neighbors, to coordinate a collaborative effort between the main art museums of the two capitals, the National Gallery of Bosnia and Herzegovina in Sarajevo and its counterpart in Banja Luka. Their efforts to obtain government support for this 


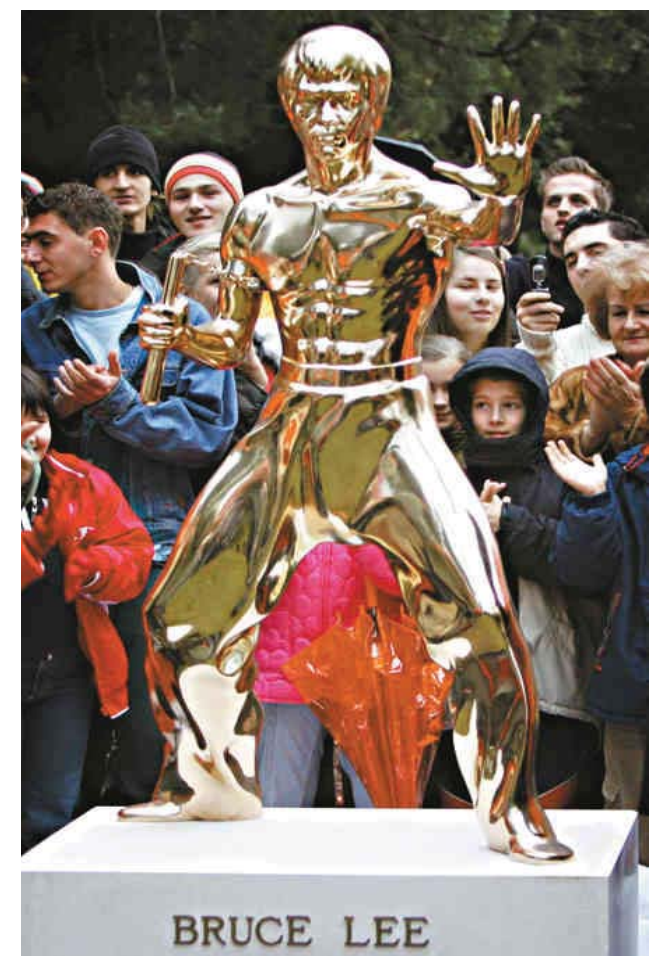

Figure 5. Bruce Lee, Mostar

endeavor did not meet with success. In an interview with a Canadian arts administrator, Susan Kennard, Assistant Curators of the National Gallery Maja Bobar and Ivana Udovičić related an anecdote that they believe reveals an understanding, and in some quarters fear, of the power of art to overcome the divisive force of nationalism. The then high representative, Paddy Ashdown, in response to a complaint about the lack of governmental support or policy for the arts, replied that "culture is a luxury." 86 The gallery staff's facetious response was to begin rubber-stamping "luxury" on all their invitations. Maja Bobar stated in all seriousness, if cynically: "I think that those politicians know, that's my opinion, very well that culture [is] very powerful. It is very important not to develop it, to support it. That is why it is in the Dayton Agreement; culture education and sport are at the lowest level of administration at this Canton level because they don't want to have a powerful cultural scene . . . it can unite people ... that is why Mr. Paddy said Culture is Luxury." ${ }^{87}$ 
Maja Bobar's observation suggests that there is a danger, in any society, in relegating the arts to the periphery, and even more so in Bosnia and Herzegovina. It is difficult to document the achievements of the arts in support of the important goals of postwar Bosnian society (reconciliation, recovery, and the growth of civil society). They are rarely directly attributable to the arts in the way that the installations of Danica Dakić and Kurt and Plasto and the public debate organized by the SCCA are considered responsible for the return of the busts of classic Yugoslav writers to the plinths on Liberation Square. Yet, this often subtle power should not be ignored or dismissed.

While visiting the War Crimes Tribunal in The Hague, Lawrence Weschler was inspired by a conversation he had had with the then president of the court, Antonio Cassese. Cassese told Weschler that when he felt in danger of being overwhelmed by the horrors that he had to confront in connection with the Yugoslav wars, he would visit the Mauritshuis Museum, to "spend a little time with the Vermeers." 88 This reply prompted Weschler to do the same, and he came to understand the connection between Vermeer's artwork and the historical calamities of his time - the aftermath of the Thirty Years' War and three wars between England and the Netherlands that spanned all of Vermeer's adult life (1652-74). Weschler became convinced of Vermeer's ability (and intent?) to combat inhumanity and to provide solace.

A talented - and powerful - group of women writers, artists, filmmakers, and arts administrators in Bosnia and Herzegovina have embraced the multifaceted power of art. In art's affirmation of beauty and civilization, it reassures us that humanity has prevailed in the past, and will again. Yet, the women profiled here refuse to limit themselves only to the potentially salutary effects of aestheticism. Their art engages the uncomfortable truths, and lies, of contemporary Bosnian society. It redirects the public gaze onto the issues and people who have been relegated to the margins. At the same time art provides a neutral ground for reconsideration. It is true, as is often said, that the war changed everything. Yet, among the transformations, many women artists and arts administrators have entered public life and have engaged "engaged" art. They create or administer art in the interface between the world of art and politics, in a relationship most would have shunned within the ideological constraints of Yugoslavia. Along with women's dominance in NGOs and their increasing role in the free press, women in the arts and arts administration deserve serious consideration as a significant sphere of influence in postwar and postsocialist Bosnian society, and particularly for their contribution to recovery, reconciliation, and the development of civil society. 


\section{Notes}

\section{Acknowledgements}

I am grateful for the financial support that funded two research trips to Bosnia and Herzegovina: to the International Research and Exchanges Board (IREX) for a Short-Term Travel Grant in 2005, to Boston College for a Research Expenses Grant in 2008, and to the Dean of Arts and Sciences of Boston College for supplemental support for my research in 2008.

Many colleagues and friends have provided encouragement, expertise, and "entrée" along the way. I do not assume, however, that they will necessarily agree with my interpretations or conclusions. They share concerns about the fate of Bosnia and Herzegovina, and some of them number among the postwar Bosnian diaspora: Damir Arsenijević, Muharem Bazdulj, Nura Bazdulj-Hubijar, Tone Bringa, Ann Kramer Borčić, Željko Borčić, Ferida Duraković, Dina Iordanova, Trevor Jockims, Jelka Kebo, Alma Lazarevska, Nataša Milas, Vildana Selimbegović, Jasminka Śišić-Saradžić, Jasmina Smajlović, Ajla Terzić. Sincere thanks and respect to them all. This monograph comes too late to thank our friend, now departed, Kemal Bakaršić.

I am indebted to two anonymous evaluators and the editors at the Carl Beck Papers for their careful reading and professional assistance.

With gratitude, above all, to Richard Niedringhaus, my saputnik, in Bosnia and beyond.

1. Although the expanded influence since the war of fundamentalist Islamic beliefs and practices on the private and public lives of women in $\mathrm{BiH}$ demands further critical and academic attention, the scholarship of Dr. Zilka Špahić-Šiljak has demonstrated that the interpretations of sacred texts in all three Abrahamic religions in BiH have buttressed patriarchal attitudes toward women's roles. See Zilka Špahić-Šiljak, Žene, religija i politika: Analiza utjecaja interpretativnog religijskog naslijeđa judaizma, kršćanstva i islama na angažman žene u javnom životu i politici [Women, religion and politics: An analysis of the influence of the interpretive religious heritage of Judaism, Christianity, and Islam on woman's engagement in public life and politics] (Sarajevo: Internacionalni multi-religijski i interkulturni centar IMIC Zajedno, etc., 2007).

2. For the need to include women in peace negotiations and general peacemaking, see Swanee Hunt and Cristina Posa, "Women Waging Peace," Foreign Policy 124 (2001) 38-47. On the specific effects of war on women and their particular relationship to war, see Jennifer Turpin, "Many Faces: Women Confronting War," in Lois Ann Lorentzen and Jennifer Turpin, eds., The Women and War Reader (New York: New York University Press, 1998), 3-18. On women's potential to contribute to economic - and general- recovery in $\mathrm{BiH}$, see Gayle Tzemach, "Overcoming Obstacles: How Women Are Rebuilding Bosnia," Center for International Private Enterprise, Economic Reform Feature Service, http://www.cipe.org/publications/fs/pdf/031507.pdf (2007); and Viet Q. Nguyen-Gillham, "Bosnian Women and Social Reconstruction: Reweaving the Social Fabric" (Ph.D. diss., Boston University, 1999), 119-120, 293-302 passim.

3. Marlise Simons, "Landmark Bosnia Rape Trail: A Legal Morass," New York Times, 29 July 1998. 
4. Cheryl Lee Robertson and Laura Duckett, "Mothering during War and Postwar in Bosnia," Journal of Family Nursing Vol. 13, No. 4 (2007): 461-483.

5. As a gateway to an extensive bibliography, see Margaret Randolph-Higonnet et al., Behind the Lines: Gender and the Two World Wars (New Haven, Conn.: Yale University Press, 1987); Cynthia Simmons and Nina Perlina, Writing the Siege of Leningrad (Pittsburgh, Pa.: University of Pittsburgh Press, 2002); and Laurie S. Stoff, They Fought for the Motherland: Russia's Women Soldiers in World War I and the Revolution (Lawrence: The University Press of Kansas, 2006).

6. Tzemach, "Overcoming Obstacles: How Women Are Rebuilding Bosnia," Center for International Private Enterprise, http://www.cipe.org/publications/fs/pdf/031507.pdf (2007).

7. "Women enjoy equal rights with men in all spheres of state economic and social life. Women are entitled to a salary equal to that of men for the same work, and enjoy special protection in the labour relationship. The state particularly protects the welfare of mother and child by the establishment of maternity hospitals, children's homes and day nurseries, and by ensuring the right to paid leave before and after confinement." Quoted in Sabrina P. Ramet, "In Tito's Time," in Sabrina P. Ramet, ed., Gender Politics in the Western Balkans (University Park: Pennsylvania State University Press, 1999): 94.

8. Ibid., 96.

9. Mikhail Bakhtin, Rabelais and His World, trans. by Helen Iswolsky (Bloomington: Indiana University Press, 1984), 49; Victor Turner, "Liminal to Liminoid, in Play, Flow, and Ritual: An Essay in Comparative Symbology," Rice University Studies 60 (Summer 1974): 53-92; Pamela Blotner, "Art Out of the Rubble," in Eric Stover and Harvey M. Weinstein, eds., My Neighbor, My Enemy: Justice and Community in the Aftermath of Mass Atrocity (Cambridge: Cambridge University Press, 2004), 270.

10. For a chronology of this opposition, which includes Oskar Davičo's paper "Poetry and Oppositions" (1949), Petar Šegedin's “About Criticism” (1949), and Miroslav Krleža's more controversial speech at the 1952 congress of the Yugoslav Writers Association, calling for a "leftist" but politically uncensored practice of literature, see Thomas Eekman, Thirty Years of Yugoslav Literature, 1945-1975 (Ann Arbor: Michigan Slavic Publications, 1978), 11-14.

11. Blazevic, Dunja. "Women of the War," Women Beyond Borders, http://www.womenbeyondborders.org/j_bosnia.htm (2009).

12. On the numerous ramifications of the power and influence of NGOs in postwar BiH, see Elissa Helms, "Women As Agents of Ethnic Reconciliation? Women's NGOs and International Intervention in Bosnia and Herzegovina," Women's Studies International Forum Vol. 26, No. 1 (2003): 15-33; and Cynthia Simmons, "Women's Work and the Growth of Civil Society in Post War Bosnia," Nationalities Papers 35 (2007): 171-185. With regard specifically to writers in the successor states of Yugoslavia, the ex-patriot Croatian writer Dubravka Ugrešić has expressed 
her trademark skepticism about the seemingly salutary effects of the support and involvement of the "international community" and the motives underlying an artistic turn toward "Western" values (civil society, multiculturalism, etc.): "The number of 'patrons' and 'commissions' of artwork has proliferated, and the intellectual notices this immediately. In the old days, during communism, it was seen as a disgrace to accept a state commission for a work of art; only the lowest of the low sold their soul to the devil. These new NGO devils seem to be good guys. If they want you to play their song for the money they've paid, then why not?" (Dubravka Ugrešić, Nobody's Home [Rochester, N.Y.: Open Letter, 2008], 167). To save the reader from cynicism, however, we might note that although Ugrešić does not ordinarily receive NGO support, she has turned since the war from the aestheticism that previously characterized her writing to the very "engagement" that she and most other writers shunned during the communist era —as in the social commentary of Nobody's Home.

13. See Bosanskohercegovačka bibliografija monografskih publikacija 1992-1996, ed. Enes Kujundžić et al. (Sarajevo: Nacionalna i univerzitetska biblioteka Bosne i Hercegovine, 1998).

14. Moranajak-Bamburać, Nirman. "Lekcije o granici," Open Book. http://www.openbook.ba/. Unless otherwise noted, all translations from Bosnian are my own (CS).

15. Alma Lazarevska, Biljke su nešto drugo (Sarajevo: Buybook, 2003).

16. Lazarevska depicts the "precedent" for this emotional state in another story in the collection, "The Red Pelerine" ("Crveni pelerina"), in which the woman narrator prepares to welcome home her husband from the front (the outreaches of Sarajevo). The action of donning the red cape seems an act of defiance against the aggressor - or an act of conjuring, which assures his safe return.

17. See Amir Brka, “Soba sa pogledom na život,” Dani, 20 July 2001.

18. The newsmagazine took its name from the Bosnian golden lily, which was the main motif on the coat-of-arms of the dynasty of Tvrtko I in medieval Bosnia, before the Turkish incursion. During the Bosnian War, the lily came to represent the Bosniak population, and it appears on the flag of the Federation of $\mathrm{BiH}$.

19. Interview with Jasna Šamić, Dani, 26 October 1998.

20. Asmir Kujović, “Tri dnevnika o ljubavi_Jasna Šamić,” Dani, 10 November 1997.

21. Jasna Šamić, Soba s pogledom na okean (Tešanj: Centar za kulturu i obrazovanje Tešanj, 2001).

22. Jasna Šamić, Carstvo sjenki (Zagreb-Sarajevo: Naklada ZORO, 2007).

23. Cf. Part 1 of Cynthia Simmons, "Bosnian War Literature and the Prose of Alma Lazarevska," The South Slav Journal Vol. 22 (Autumn-Winter, 2001): 56-69. 
24. The narrator's reference to her "twin brother's" emigration invokes a recurring theme in the novel, of whether departure from Bosnia during the war rates as "betrayal."

25. Bosnian Letter http://www.orbus.be/literatura/nura_bazdulj_hubijar.htm

26. “I Write So That People Will Be Better,” Dani, 18 November 2005.

27. I refer to the Kirche (church) of Bismarck's famous triad of Kinder, Küche, and Kirche (children, kitchen, and church), now employed in feminist scholarship (and devoid of any association to Nazi ideology) to denote the traditionally prescribed domains of women.

28. Nura Bazdulj-Hubijar, Kad je bilo juli (Zagreb: V.B.Z., 2005).

29. In the Yugoslav era, words that entered the Slavic linguistic territory (of what we consider today Bosnian, Croatian, and Serbian) during Ottoman rule were considered "Turkishisms" (turcizmi), regardless of whether these words originated in the Turkish language or in the Arabic of Muslim religious texts. Mirza's use of "Turkishisms" reveals more about his rural Bosniak (rather than urban multi-ethnic) origin than it does about his religious beliefs.

30. From Turkish, a provincial spiritual leader (imam).

31. Mirza refers to a Bosnian member of the Orthodox Church (his fiancée) with this traditional term. The Vlachs were, in fact, a nomadic people who preceded and were distinctive from the Slavs of Southeastern Europe. However, they intermingled and assimilated with nomadic Serbs, particularly when they migrated north, into Bosnia, to escape the advancing Ottoman Turks (Noel Malcom, Bosnia: A Short History [New York: New York University Press 1994], 72-81).

32. Damir Arsenijević, "Poezija razlika u Bosni i Hercegovini-negiranje dominantnoj ideologiji monopola vjerodostojnosti" (Poetry of differences in Bosnia and Herzegovina - denying the dominant a monopoly of plausibility, paper given at the conference "Bosnia and Herzegovina: Ten Years of Dayton and Beyond," 20-21 October 2005, Geneva).

33. Edisa Gazetić, “'Fenomen’ ženskog pisma/identiteta u Bosanohercegovačkoj književnosti,” Patchwork Vol. 1, Nos. 1-2 (2003): 100-101.

34. Ferida Duraković, Locus minoris (Sarajevo: Connectum, 2007).

35. Arsenijević, "Poezija razlika," 4.

36. Adisa Bašić, Trauma-Market (Sarajevo: Omnibus, 2004), 19. That those who experience trauma carry it with them forever, and that the experience informs their lives long after the overt reminders - like refugees along the road-have disappeared, she conveys in the epigraph to the eponymous section of the collection "Trauma-Market": "- Od čega? (odgovor Zidova koji je preživio holokaust na pitanje da li je otišao na Novi Zeland da bi bio što dalje)" (From what? [the answer of a Jewish man who had survived the Holocaust to the question of whether he had 
moved to New Zealand to be as far away as possible]).

37. Adisa Bašić-Čečo, “Dnevnik,” Sarajevski sveske, nos. 19-20 (2008): 53.

38. Conversation with writer, July 2008, Sarajevo.

39. Ajla Terzić, "Cornflake Girl,” in Kako teško pišem (Omnibus: Sarajevo, 2004).

40. On 11 July 1995, when it appeared that Serb forces would overrun Srebrenica, Bosnia, more than twenty thousand refugees fled to the nearby village of Potočari. A war memorial and cemetery have since been established there, across from a battery factory that formerly housed UN troops positioned to protect the "safe area," and where some of the atrocities eventually occurred.

41. Alec Leamas is the principal character in spy novels by John Le Carré, including The Spy Who Came in from the Cold.

42. Blotner, "Art out of the rubble," in Eric Stover and Harvey M. Weinstein, eds., My Neighbor, My Enemy (Cambridge: Cambridge University Press, 2004), 269. Women did not commonly serve in the armed forces or paramilitary units of any of the combatants.

43. Kennard, Susan. "What Does Art Matter," Glocal Times, http://www.glocaltimes.k3.mah.se/viewarticle.aspx?articleID=31\&issueID=4 .

44. The Washington Times, 22 December 2008 (from the Associated Press).

45. Kennard, "What Does Art Matter?," 8.

46. Blotner, "Art Out of the Rubble," 269.

47. Kennard, "What Does Art Matter?," 8.

48. "Brief History of Bosnian $20^{\text {th }}$ Century Art," Bosnian Institute, http://www.bosnia.org.uk/bosnia/viewitem.cfm?itemID=379\&typeID=186

49. Although not directly relevant to the authors profiled here, emigration has affected Bosnian writers in a similar way. Aleksandar Hemon (Chicago/Sarajevo) has achieved international acclaim (he writes primarily in English); Miljenko Jergović claims dual residence (Croatia and $\mathrm{BiH})$ and is often claimed as "most famous writer" by both countries; and the poet Semezdin Mehmedinović (US/BiH) writes a column (as does Hemon) for the newsmagazine Dani.

50. Despite the public discussion in Sarajevo concerning the return of Andrić's bust, it was preserved, unlike the statue of Andrić in the eastern Bosnian town of Višegrad, the setting for his famous novel The Bridge on the Drina, which was destroyed. Celia Hawkesworth examines the complex issue of Ivo Andrić's ethnicity in "Ivo Andrić as Red Flag and Political Football," Slavonic and East European Review Vol. 80, No. 2 (2002): 201-216. 
51. Blažević, Dunja. "Neighbors,” Cultural Aid, http://www.culturalaid.com/bosna.htm.

52. City of Women http://www.cityofwomen.org/2005/en/program/mesto-zensk/bajevic (site now discontinued). See Sabrina Petra Ramet, Balkan Babel (Boulder, Colo.: Westview Press, 1996), which dedicates an entire chapter to the influence on rising nationalism of folk-inspired popular music. See also Dubravka Ugrešić, The Culture of Lies (University Park, PA: Pennsylvania State University Press, 1998), 128-150, and Eric Gordy, "Rokeri i turbaši as Windows into Serbia's Social Divide," Balkanologie Vol. 4, No. 1 (2000): 55-82.

53. Sarajevo-x.com http://www.sarajevo-x.com/clanak/060915040 (2006).

54. Elissa Helms, "East and West Kiss: Gender, Orientalism, and Balkanism in Muslim Majority Bosnia-Herzegovina," Slavic Review Vol. 67, No. 1 (2008): 111-113.

55. Šejla Kamerić was also chosen (along with Maja Bajević and Danica Dakić) to represent $\mathrm{BiH}$ in the international exhibition Eastern Neighbors. She submitted Bosnian Girl.

56. Dina Iordanova, "Hidden Histories on Film: Female Director from South Eastern Europe," ms., 2 .

57. In an interview with the on-line magazine Aviva, Jasmila Žbanić described how the response to her film in BiH encouraged her to further action - the campaign "For the Dignity of Women." After screenings of the film, activists collected signatures on petitions that demanded that survivors of rape become eligible for the special assistance that veterans and refugees can receive. (http://www.avivaberlin.de/aviva/content_Women\%20+\%20Work_Leading\%20Ladies. php?id+8309).

58. Snijeg received, among other awards, the 2008 Cannes Critics’ Week Grand Prize.

59. Aida Begić, “Snijeg je eksces,” Dani, 15 August 2008.

60. The title also invites the viewer to consider the conceit of Orhan Pamuk's novel Snow. In Begić's film, "businessmen" arrive in Slavno hoping to purchase land and are stranded by a rainstorm, which turns to snow. Similarly in Pamuk's novel, the writer protagonist travels to the town of Kars, ostensibly to investigate the suicides of the "head-scarf girls." He is stranded in Kars by a snowstorm, with no exit from the dangerous truths that his inquiry has begun to reveal.

61. Begić, "Snijeg je eksces."

62. See Amy Taubin, “Documenting Women,” Ms. Magazine, Summer 2004.

63. Popmatters. "Depth of Field: An Interview with Filmmaker Danijela Majstorovic," http://www.popmatters.com/pm/post/depth-of-field-an-interview-with-filmmaker-danijelamajstorovic (2006).

64. Vedrana Seksan, “Šuti, ženska glavo,” Dani, 31 January 2003. 
65. Ibid.

66. Unfortunately, despite the attention this declaration garnered in the media, it produced no substantive improvement in work conditions or financial support.

67. Dževad Karahasan explores the multiethnic and often multicultural character of central prewar Sarajevo, with apparent application to other urban centers in $\mathrm{BiH}$, in "Sarajevo: Portrait of an Internal City," in Joanna Labon, ed., Balkan Blues (Evanston, Ill.: Northwestern University Press, 1994): 89-103.

68. The University of Mostar (formerly the Džemal Bijedić University in Mostar) is now the only "Croatian-language" university in $\mathrm{BiH}$ - an artificial distinction within a town whose inhabitants speak essentially the same dialect. The signing of the Bologna declaration by $\mathrm{BiH}$ in 2003 will force greater cooperation between the university and the postwar campus established in eastern (Bosniak) Mostar.

69. As a result of an influx of Bosniak refugees during the war (and the exodus of most of the ethnic Serb population), the Muslim majority in Zenica rose from fifty-five percent in 1991 to eighty-five percent in 2005. On the necessity or desirability of attending medical school in Zenica, see the preceding note.

70. In expressing her sincere motivation to promote the arts in a leadership role, Jelka Kebo conforms to a discursive strategy common to women in politics as well: "rather than a bid for personal status, power, or gain, the impetus for women's involvement in politics is a noble sacrifice made on behalf of children and their future. In this way they have rooted their political presence in traditionally womanly roles" (Elissa Helms, "Politics Is a Whore," in Xavier Bougarel, Elissa Helms and Ger Duijzings, eds., The New Bosnian Mosaic [Burlington, Vt.: Ashgate Publishing Company, 2007], 247).

71. See Kultura Balkanica, www.kulturabalkanica.be (2008).

72. See Swanee Hunt, This Was Not Our War (Durham, N.C.: Duke University Press, 2004), 221.

73. In Voices in the Shadows: Women and Verbal Art in Serbia and Bosnia (Budapest: CEU Press, 2000), Celia Hawkesworth singles out Duraković as representing the most talented women poets of the second postwar generation (262).

74. Marina Trumić and Ferida Duraković, eds., Književnost i izazovi politike: Transkript razgovora 2006-2007. godine (Sarajevo: PEN Centar Bosne i Hercegovine, 2008).

75. From private correspondence with Ferida Duraković.

76. The museum is occasionally referred to in English, in literal translation, as the "Land Museum." 
77. Discussion and interview with Jasminka Šišić-Saradžić, curator and preparator in the Department of Material Culture, July 2008 and December 2008).

78. The history of the Sarajevo Haggadah has again captured international attention with the publication of Geraldine Brooks's novel The People of the Book (New York: Viking, 2008). For a scholarly account of the rescue and preservation of the book in WWII and the recent Bosnian War, see "Rukopisni kodeks C-4436 Zemaljskog muzeja Bosne i Hercegovine poznatiji kao Sarajevska Haggada" (Manuscript Codex C-4436 of the National Museum of Bosnia and Herzegovina better known as the Sarajevo Haggadah) in Kemal Bakaršić, Fragmenti kulturne historije Bosne i Hercegovine (Sarajevo: Magistrat, 2005), 147-192.

79. Buturović, Đenana: The National Museum of Bosnia and Herzegovina: its emergence and its fall in the overall destruction of Bosnia Herzegovina (from April 1992 to the end of 1995). Wissenschaftliche Mitteilungen des Bosnisch-Herzogowinischen Landesmuseums A VII / B IV/C VII (2000): 7-60. Dr. Tone Bringa (an anthropologist and the author of Being Muslim the Bosnian Way (Princeton, N.J.: Princeton University Press, 1995) preceded her presentation at the 2005 conference at the National Museum in Sarajevo, "Ethnology Meets Museum," by recognizing the courage and dedication of the museum staff during the siege.

80. Charles Landry, Togetherness in Difference: Culture at the Crossroads in Bosnia-Herzegovina, Cultural Policy in Bosnia-Herzegovina: Experts Report, European Program of National Cultural Policy Reviews, Steering Committee for Culture, Council of Europe. This report was presented and accepted at the first plenary session, Strasbourg, 9 October 2002.

81. Dunja Blažević, "What Do We Have in Common," in Hannes Swoboda and Christophe Solioz, eds., Conflict and Renewal: Europe Transformed (Essays in Honour of Wolfgang Petritsch) (Baden-Baden: Nomos, 2007), 210-211.

82. Ibid., 211-212.

83. Dunja Blažević, "Who Owns Public Spaces? The Ownership of Monuments," in Hannes Swoboda and Christophe Solioz, eds., Conflict and Renewal: Europe Transformed (Essays in Honour of Wolfgang Petritsch) (Baden-Baden: Nomos, 2007), 353n.

84. Ibid., 352-353.

85. "De/construction of Monument," Projekt Relations, www.projekt-relations.de/en/explore/deconstruction/veranstaltung.php (2005).

86. Susan Kennard, "What Does Art Matter," 4-5. The Office of the High Representative was established by the Dayton Peace Agreement (1995) to ensure the implementation of civilian aspects of the peace treaty. The high representative (currently Valentin Inzko, an Austrian of Slovenian heritage, appointed in 2009) is now also the EU Special Representative. The OHR has been extended indefinitely until $\mathrm{BiH}$ satisfies particular requirements.

87. Ibid., 5 .

88. Lawrence Weschler, "Vermeer in Bosnia," in Vermeer in Bosnia (New York: Pantheon Books, 2004), 14. 

Center for Russian \& East European Studies

University Center for International Studies

University of Pittsburgh

4400 W. W. Posvar Hall

230 South Boquet Street

Pittsburgh, Pennsylvania 15260

(412) 648-8716

www.ucis.pitt.edu/crees/cbpaper.html.

Ronald Linden, Bob Donnorummo, William Chase, Co-Editors Eileen O’Malley, Managing Editor Julie Tvaruzek, Editorial Assistant 